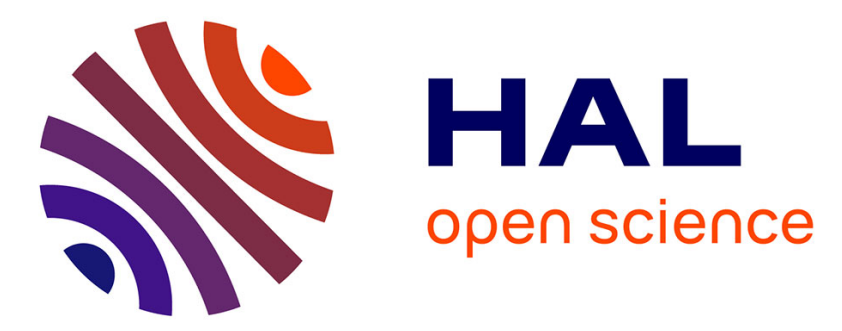

\title{
Abiotic degradation of highly branched isoprenoid alkenes and other lipids in the water column off East Antarctica
}

\author{
Jean-Francois Rontani, Lukas Smik, Simon Belt, Frederic Vaultier, Linda \\ Armbrecht, Amy Leventer, Leanne Armand
}

\section{To cite this version:}

Jean-Francois Rontani, Lukas Smik, Simon Belt, Frederic Vaultier, Linda Armbrecht, et al.. Abiotic degradation of highly branched isoprenoid alkenes and other lipids in the water column off East Antarctica. Marine Chemistry, 2019, 210, pp.34-47. 10.1016/j.marchem.2019.02.004 . hal-02325661

\section{HAL Id: hal-02325661 \\ https://hal.science/hal-02325661}

Submitted on 22 Oct 2021

HAL is a multi-disciplinary open access archive for the deposit and dissemination of scientific research documents, whether they are published or not. The documents may come from teaching and research institutions in France or abroad, or from public or private research centers.
L'archive ouverte pluridisciplinaire HAL, est destinée au dépôt et à la diffusion de documents scientifiques de niveau recherche, publiés ou non, émanant des établissements d'enseignement et de recherche français ou étrangers, des laboratoires publics ou privés.

\section{(ㄷ)(1) $\$$}

Distributed under a Creative Commons Attribution - NonCommerciall 4.0 International 

and other lipids in the water column off East Antarctica

${ }^{a}$ Aix Marseille Université, Université de Toulon, CNRS/INSU/IRD, Mediterranean Institute of 8 Oceanography (MIO), UM 110, 13288 Marseille, France

${ }^{b}$ Biogeochemistry Research Centre, School of Geography, Earth and Environmental Sciences, University of Plymouth, Drake Circus, Plymouth, Devon PL4 8AA, UK

${ }^{c}$ Australian Centre for Ancient DNA, School of Biological Sciences, Faculty of Sciences, The University of Adelaide, Adelaide, South Australia, 5005, Australia

${ }^{d}$ Department of Geology, Colgate University, Hamilton, NY 13346, USA

${ }^{e}$ Research School of Earth Sciences, The Australian National University, Acton, Australian Capital 
Abstract. In some previous studies, the ratio between a di-unsaturated highly branched isoprenoid (HBI) lipid termed $\mathrm{IPSO}_{25}$ and a structurally related tri-unsaturated counterpart (HBI III) (viz. IPSO ${ }_{25} / \mathrm{HBI}$ III) has been used as a proxy measure of variable sea ice cover in the Antarctic owing to their production by certain sea ice algae and open water diatoms, respectively. To investigate this further, we quantified selected lipids and their photo- and autoxidation products in samples of suspended particulate matter (SPM) collected at different water depths in the polynya region west of the Dalton Iceberg Tongue (East Antarctica). The results obtained confirm the high efficiency of photo- and autoxidation processes in diatoms from the region. The systematic increase of the ratio $\mathrm{IPSO}_{25} / \mathrm{HBI}$ III with water depth in the current samples appeared to be dependent on the sampling site and was due to both (i) a relatively higher contribution of ice algae to the deeper samples resulting from their increased aggregation and therefore higher sinking rate, or (ii) a stronger abiotic degradation of HBI III during settling through the water column. Analyses of samples taken from the water-sediment interface and some underlying near-surface sediments revealed a further increase of the ratio $\mathrm{IPSO}_{25} / \mathrm{HBI}$ III, indicative of further differential oxidation of the more unsaturated HBI. Unfortunately, specific oxidation products of HBI III could not be detected in the strongly oxidized SPM and sediment samples, likely due to their lability towards further oxidation. In contrast, oxidation products of HBI III were detected in weakly oxidized samples of phytoplanktonic cells collected from Commonwealth Bay (also East Antarctica), thus providing more direct evidence for the involvement of photo- and/or autoxidation of HBI III in the region. This oxidative alteration of the ratio $\mathrm{IPSO}_{25} / \mathrm{HBI}$ III between their source and sedimentary environments might need to be considered more carefully when using this parameter for palaeo sea ice reconstruction purposes in the Antarctic. 
51 Key words: East Antarctica; Suspended particulate matter; Near-surface sediments; Lipids;

52 Photo- and autoxidation; Alteration of $\mathrm{IPSO}_{25} / \mathrm{HBI}$ III ratio; Paleoceanographic implications. 


\section{Introduction}

Sea ice plays a central role in the overall climate structure of the Polar Regions (Thomas, 2017). Amongst its various well known attributes, its high albedo (reflectivity) means that sea ice serves as an efficient regulator of incoming solar radiation to the surface oceans. Further, the physical structure of sea ice provides a physical barrier to the exchange of gas, heat and moisture between the polar oceans and the atmosphere. It is also an important contributor to near-surface stratification, bottom-water formation and ventilation, in particular (e.g. Dickson et al., 2007 and references therein). From a biogeochemical perspective, nutrient release during ice melt in spring, coupled with surface layer stratification and increasing light and temperature, often leads to intense open water phytoplankton production, especially along the retreating ice edge or the so-called marginal ice zone (MIZ) (Smith and Nelson 1986; Smith, 1987; Sakshaug et al., 2009; Perette et al., 2011).

Understanding the well documented abrupt changes in sea ice in the polar regions (Stroeve et al., 2012; Fetterer et al., 2016, Serreze et al., 2016; Walsh et al., 2017) requires more detailed knowledge of how it has changed in the past in response to other climatic drivers. A common approach to achieve this is through the analysis of so-called sea ice proxies present in marine sediment archives. The majority of these proxies possess some kind of biological origin, although there are others (e.g. de Vernal et al., 2013 and references therein). In the Antarctic, the identification of certain ice-associated diatoms in polar marine sediments has a long history of use for palaeo sea ice determinations (Armand et al., 2017). However, the growth habitat of the target species are normally more closely associated with the open waters of the MIZ rather than that of sea ice itself (Leventer, 1998; Leventer et al., 2008). On the other hand, those diatoms that bloom within the sea ice 
host (i.e. the strictly sympagic community), are often under-represented in sedimentary records (Leventer, 2013).

Over the last decade or so, a number of diatom-derived lipid biomarkers have emerged as useful complementary sea ice proxies to the more traditional micropaleontological-based approaches. Thus a mono-unsaturated highly branched isoprenoid (HBI) termed IP 25 (Ice Proxy with 25 carbon atoms; Belt et al., 2007) has emerged as a useful proxy for seasonal Arctic sea ice (for reviews, see Belt and Muller, 2013; Belt, 2018), while a di-unsaturated structural homolog of $\mathrm{IP}_{25}$ - sometimes referred to as HBI II (1; see appendix) - appears to be a suitable counterpart for the Antarctic. A recent source identification and the near ubiquity of the diene $\mathbf{1}$ in near-coastal sediments from around the Antarctic continent has led to its recent designation as $\mathrm{IPSO}_{25}$ (Ice Proxy for the Southern Ocean with 25 carbon atoms; Belt et al., 2016) by analogy with $\mathrm{IP}_{25}$. A further, tri-unsaturated HBI, often termed HBI III (2), is also showing potentially as a biomarker proxy indicator of the MIZ in both Polar Regions. Thus, enhanced concentrations of HBI III (2) have been observed in surface sediments from the MIZ of the Barents Sea in the Arctic (Belt et al., 2015) and in surface waters of the MIZ in East Antarctica (Smik et al., 2016) and the Scotia Sea (Schmidt et al., 2018) shortly following sea ice melt. As a result, some palaeo sea ice records based on HBI II (hereafter referred to as $\mathrm{IPSO}_{25}$ ) (1) and HBI III (2) for the Antarctic have appeared in recent years (Barbara et al., 2010,2013,2016; Denis et al., 2010; Collins et al., 2013; Etourneau et al., 2013; Campagne et al., 2015,2016). A general interpretation of greater sea ice extent for relatively high $\mathrm{IPSO}_{25}$ (1) compared to $\mathrm{HBI}$ III (2), and more open water conditions for increased HBI III (2) concentrations has been applied. In some of these studies, variability in the ratio $\mathbf{1 / 2}$ has been used as a qualitative measure of changes to sea ice cover; however, this assumption has, as yet, not been validated through comparison of surface 
sediment biomarker data with known overlying sea ice conditions in the same way as for $\mathrm{IP}_{25}$ (and HBI III (2) in some cases) in the Arctic (see Belt, 2018 for a recent review). Nonetheless, such interpretations are consistent with the data reported by Smik et al. (2016) following analysis of $\operatorname{IPSO}_{25}$ (1) and HBI III (2) in surface waters from regions of variable sea ice cover from East Antarctica, with highest concentrations found in the summer sea ice zone and MIZ, respectively. Similar findings have also been reported for surface water samples from the Scotia Sea (Schmidt et al., 2018). However, the extent to which the surface water distributions of $\operatorname{IPSO}_{25}(\mathbf{1})$ and HBI III (2) are replicated in the underlying sediments for palaeo sea ice reconstruction purposes was not investigated in the initial study by Smik et al. (2016).

To provide further insight to this, here we carried out analysis of further water samples from the polynya region proximal to the Dalton Ice Tongue in East Antarctica with the primary aim of determining any variability of the ratio $\mathbf{1 / 2}$ with water depth, and to reconcile outcomes through the identification of pathway-specific oxidation products of common phytoplankton lipids as indicators of well-known degradation processes (i.e. bacterial degradation, photooxidation and autoxidation). Further evidence for the oxidation of such lipids was obtained through the analysis of near-surface sediment material collected from the main study region and from filtered phytoplankton samples collected from Commonwealth Bay (also East Antarctica).

\section{Materials and methods}

\subsection{Sampling}

Water samples were obtained as part of the NBP1402 cruise aboard the RVIB 
see also NBP1402 Scientific Cruise Report, 2014, Sabrina Coast: Marine record of cryosphere-ocean dynamics (467 pages) for further details) (http://www.marinegeo.org/tools/search/data/field/NBPalmer/NBP1402/docs/NBP1402Cru iseReport_Final.pdf). For the current study, we focused on those locations that had experienced seasonal sea ice cover within the polynya region west of the Dalton Iceberg Tongue (East Antarctica). At each of the 12 sampling sites (Fig. 1), surface (0-10 m), subsurface (chlorophyll $a$ maximum; ca. 25-60 m) and deep (ca. 500-1100 m) water samples were obtained from CTD rosettes. At the five stations where we carried out lipid degradation studies, the surface CTD samples had already been used for native lipid $1.1 \mathrm{mg} \mathrm{d}$.w. $\left.\mathrm{ml}^{-1}\right)$ were stored frozen $\left(-20^{\circ} \mathrm{C}\right)$ prior to freeze drying and analysis. 
Lipids from all of the CTD samples, the waters above the sediment cores and the diatomaceous 'fluff' were extracted and analyzed as described previously by Smik et al. (2016). This treatment involved addition of internal standards (9-octyl-8-heptadecene for HBI quantification, $5 \alpha$-androstan-3 $\beta$-ol for $\Delta^{5}$-sterol quantification and nonadecanoic acid for fatty acid quantification), saponification $\left(5 \% \mathrm{KOH}\left(9: 1 \mathrm{v} / \mathrm{v} \mathrm{MeOH} / \mathrm{H}_{2} \mathrm{O}\right) ; 70{ }^{\circ} \mathrm{C} ; 60\right.$ $\min )$ and separation of non-saponifiable (hexane $3 \times 2 \mathrm{ml})$ and saponifiable fractions $(+1 \mathrm{ml}$ $\mathrm{HCl}$; hexane $(3 \times 2 \mathrm{ml}))$. For sediments, ca. $1 \mathrm{~g}$ of freeze-dried material was extracted by sonication (dichloromethane/methanol; $2: 1 \mathrm{v} / \mathrm{v}, 3 \times 2 \mathrm{ml}$ ) to obtain a total organic extract (TOE). Subsequent purification of the unsaponifiable fraction/TOE by open column chromatography $\left(\mathrm{SiO}_{2}\right)$ afforded $\mathrm{HBI}$ (elution with hexane; 5 column volumes) and sterols (elution with hexane-methyl acetate $(4: 1, \mathrm{v} / \mathrm{v} ; 5$ column volumes). In addition, saturated non-polar components of TOEs were removed using silver-ion chromatography (Belt et al., 2015).

Treatment of the filtered water samples from the five stations selected for lipid oxidation product analyses and phytoplankton material collected from Commonwealth Bay involved a different treatment. Following addition of $\mathrm{MeOH}(25 \mathrm{ml})$ and reduction with excess $\mathrm{NaBH}_{4}$ (70 mg, $30 \mathrm{~min}$ ) of labile hydroperoxides to alcohols, which are more amenable to analysis using gas chromatography-mass spectrometry (GC-MS), water (25 $\mathrm{ml})$ and $\mathrm{KOH}(2.8 \mathrm{~g})$ were added and the resulting mixture saponified by refluxing $(2 \mathrm{~h})$. After cooling, the mixture was acidified $(\mathrm{HCl}, 2 \mathrm{~N})$ to $\mathrm{pH} 1$ and extracted with total lipid extracts (TLEs).

A different treatment (Rontani et al., 2018) was employed to estimate the relative proportions of hydroperoxides and their ketonic and alcoholic degradation products in 
phytoplankton samples from Commonwealth Bay. This involved ultrasonic extraction of lipids with chloroform-MeOH-water (1:2:0.8, v/v/v), separation of the supernatant by centrifugation at $3500 \mathrm{G}$, evaporation to dryness, and division of the residue into two equal parts. The first sub-sample was acetylated in acetic anhydride-pyridine $(1: 2, \mathrm{v} / \mathrm{v})$ overnight, which converted hydroperoxides to the corresponding ketones (Mihara and Tateba, 1986), and then saponified. The second sub-sample was reduced with $\mathrm{NaBD}_{4}$ and saponified. Comparison of the amounts of alcohols present after acetylation and $\mathrm{NaBD}_{4}$ reduction made it possible to estimate the amount of hydroperoxides and alcohols present in the samples, while deuterium labeling (via $\mathrm{NaBD}_{4}$ reduction) allowed us to estimate the proportion of ketones in the samples.

\subsection{Derivatization}

For all samples containing hydroxylic components, an aliquot was dissolved in 300 $\mu 1$ pyridine/bis(trimethylsilyl)trifluoroacetamide (BSTFA, Supelco; 2:1, v:v) and silylated analyzed by GC-MS, GC-QTOF or GC-MS/MS.

\subsection{Assignment and quantification of lipids}

Native lipids were identified and quantified using GC-MS in total ion current (TIC) or selected ion monitoring (SIM) mode using a Hewlett-Packard 5890 Series II gas chromatograph, fitted with a $30 \mathrm{~m}$ fused silica $\mathrm{HP}_{5 \mathrm{~ms}}$ column $(0.25 \mathrm{~mm}$ i.d., $0.25 \mu \mathrm{m}$ film $)$ coupled to a 5970 Series Mass Selective Detector (MSD) (Belt et al., 2012). Individual lipids (and their derivatised products) were identified on the basis of their characteristic GC retention indices (e.g. $\mathrm{RI}_{\mathrm{HP} 5 \mathrm{~ms}} 2082$ and 2044 for $\mathrm{IPSO}_{25}$ and HBI III, respectively) and 
mass spectra (Belt, 2018), together with comparison of both parameters with those obtained from purified standards (Smik et al., 2016). Quantification of individual lipids was achieved first by manual integration of GC-MS peak areas, division of these by those of the respective internal standards, and normalization of the resulting ratios using instrumental response factors obtained for each lipid (Belt et al., 2014; Smik et al., 2016). These normalised ratios were then multiplied by the mass of the internal standard and filtered or mass of sediment extracted. All analytical data can be found in Supplementary Table 1. masses and mass spectra with those of standards and quantified (calibration with external

\subsection{Assignment and quantification of lipid oxidation products}

Lipid oxidation products were identified by comparison of retention times, accurate standards) using gas chromatography-electron ionization quadrupole time of flight mass spectrometry (GC-QTOF). GC-QTOF analyses were carried out with an Agilent 7890B/7200A GC-QTOF System (Agilent Technologies, Parc Technopolis - ZA Courtaboeuf, Les Ulis, France). A cross-linked 5\% phenyl-methylpolysiloxane (Macherey Nagel; Optima 5-MS Accent) column (30 m $\times 0.25 \mathrm{~mm}, 0.25 \mu \mathrm{m}$ film thickness $)$ was employed. Analyses were performed with an injector operating in pulsed splitless mode at $280{ }^{\circ} \mathrm{C}$ and the oven temperature programmed from $70{ }^{\circ} \mathrm{C}$ to $130{ }^{\circ} \mathrm{C}$ at $20^{\circ} \mathrm{C} \mathrm{min}{ }^{-1}$, then to $250{ }^{\circ} \mathrm{C}$ at $5{ }^{\circ} \mathrm{C} \mathrm{min}^{-1}$, and then to $300{ }^{\circ} \mathrm{C}$ at $3{ }^{\circ} \mathrm{C} \min ^{-1}$. The carrier gas (He) was maintained at $0.69 \times 10^{5} \mathrm{~Pa}$ until the end of the temperature program. Instrument temperatures were $300{ }^{\circ} \mathrm{C}$ for the transfer line and $230{ }^{\circ} \mathrm{C}$ for the ion source. Accurate mass spectra were obtained across the range $\mathrm{m} / \mathrm{z}$ 50-700 at $4 \mathrm{GHz}$. The QTOF-MS 
instrument provided a typical resolution ranging from 8009 to 12252 from $\mathrm{m} / \mathrm{z} 68.9955$ to 501.9706. Perfluorotributylamine (PFTBA) was utilized for daily MS calibration.

\subsection{Assignment and quantification of HBI oxidation products}

Quantification of HBI oxidation products was carried out using an Agilent 7850-A gas chromatograph connected to an Agilent 7010-QQQ mass spectrometer working in multiple reaction monitoring (MRM) mode. The following conditions were employed: 30 m x 0.25 mm (i.d.) fused silica column coated with HP-5MS (Agilent; film thickness: 0.25 $\mu \mathrm{m}$ ); oven programmed from 70 to $130{ }^{\circ} \mathrm{C}$ at $20^{\circ} \mathrm{C} \min ^{-1}$, then to $250{ }^{\circ} \mathrm{C}$ at $5{ }^{\circ} \mathrm{C} \mathrm{min}^{-1}$ and then to $300{ }^{\circ} \mathrm{C}$ at $3{ }^{\circ} \mathrm{C} \mathrm{min}^{-1}$; carrier gas (He), 1.0 bar; injector (splitless), $250{ }^{\circ} \mathrm{C}$; electron energy, $70 \mathrm{eV}$; source temperature, $230{ }^{\circ} \mathrm{C}$; quadrupole temperature, $150{ }^{\circ} \mathrm{C}$; scan range $\mathrm{m} / \mathrm{z}$ 40-700; collision energy, ranging from 5 to $15 \mathrm{eV}$; collision flow, $1.5 \mathrm{ml} \min ^{-1}\left(\mathrm{~N}_{2}\right)$; quench flow, $2.25 \mathrm{ml} \mathrm{min}^{-1}(\mathrm{He})$; cycle time, $0.2 \mathrm{~s}$. Oxidation products were assigned by comparison of retention times and mass spectra with those of standards. Due to the presence of two highly photo-reactive tri-substituted double bonds (C-7/20 and C-9/10) in HBI III (2), it was not possible to quantify its primary oxidation products directly using standards, since they are not accumulated due to rapid further oxidation (Rontani et al., 2014a). We therefore quantified photoproducts of a related HBI triene (3) (possessing only one reactive tri-substituted double bond (C-9/10); see appendix) as an external standard and estimated the quantities of oxidation products from HBI III (2) by applying a correction factor (Rontani et al., 2014b).

\subsection{Standard compounds}

The synthesis of 3-methylidene-7,11,15-trimethylhexadecan-1,2-diol (phytyldiol) (7) was described previously by Rontani and Aubert (2005). (8-11)-Hydroperoxyhexadec-(8- 
10)-enoic acids $(Z$ and $E)(\mathbf{3 6 - 4 1})$ and (8-11)-Hydroperoxyoctadec-(8-10)-enoic ( $Z$ and $E)$

$252 \quad(\mathbf{3 0}-35)$ acids were produced by $\mathrm{Fe}^{2+} /$ ascorbate-induced autoxidation (Loidl-Stahlhofen and Spiteller, 1994) of palmitoleic and oleic acids, respectively. Subsequent reduction of these different hydroperoxides in methanol with excess $\mathrm{NaBH}_{4}$ afforded the corresponding hydroxyacids. 3,6-Dihydroxy-cholest-4-ene (18) (employed for sterol photooxidation estimates) was obtained from Maybridge Ltd. Treatment of sitosterol (42) with metachloroperoxy-benzoic acid in dry DCM yielded a mixture of $5 \alpha, 6 \alpha$-and $5 \beta, 6 \beta$-epoxides. Heating of these epoxides in the presence of water afforded the corresponding 24ethylcholesta-3 $\beta, 5 \alpha, 6 \beta$-triol (43) (Holland and Diakow, 1979). IPSO $_{25}$ (1) and HBI triene 3 were purified from cultures of Haslea ostrearia (Belt et al., 1996; Johns et al., 1999), while HBI III (2) was obtained from a culture of Pleurosigma intermedium (Belt et al., 2000). Photosensitized oxidation products (hydroperoxides) of these HBI alkenes were produced in pyridine in the presence of haematoporphyrin as photosensitizer and then reduced with $\mathrm{NaBH}_{4}$ to the corresponding alcohols (Rontani et al., 2014a).

\subsection{Diatom taxonomy}

Diatom identification and enumeration were carried out for selected water and sediment samples. Specifically, three water samples of $200 \mathrm{ml}$ each were collected at CTD015 (5, 40, $563 \mathrm{~m})$. Overlying bottom water (100 $\mu$ l), diatomaceous fluff (50 $\mu 1)$ and sediment samples were collected from MC061. Sediment was also collected from MC045. The water samples were immediately fixed with Lugol's solution $(\sim 0.5 \mathrm{ml})$. Back at the laboratory, the preserved water samples were concentrated (CTD015) or diluted (MC061) into Utermöhl chambers to a final volume of $3 \mathrm{ml}$. After sedimentation of $48 \mathrm{~h}$, a minimum total of 400 cells (including microphyto- and microzooplankton live at the time of preservation), were identified and counted following the Utermöhl method (Utermöhl, 

1958) at a magnification of 400x under an inverted microscope (Olympus IMT-2, Japan). Microplankton were identified to species level where possible using appropriate taxonomic literature (Hasle, 1965; Tomas, 1997; Scott and Marchant, 2005, Kim et al. 2013). Final counts were converted to cells $1^{-1}$. Sediment samples were dried at $50{ }^{\circ} \mathrm{C}$. Quantitative slides were made using a settling method (Scherer, 1994). Approximately $5 \mathrm{ml}$ of water and hydrogen peroxide was added to several mg of each sample, and the samples were placed on a warming tray at $50{ }^{\circ} \mathrm{C}$ for $2-3$ days. After complete reaction and removal of organic material, the samples were poured into water-filled 11 beakers and allowed to settle onto coverslips. The coverslips were mounted on glass slides using Norland Optical Adhesive \#61 cured under UV light. These quantitative slides were used for assessment of the diatom assemblage, by identification and counting of a minimum of 400 diatom valves along cross-slide transects, at a magnification of 1000x. Counting followed the method described by Schrader and Gersonde (1978) and Crosta and Koc (2007). Diatom concentration (diatom valves per gram) and relative abundance (percentage) of diatom species were calculated.

For the purposes of the current investigation, we determined the distribution of three common Fragilariopsis spp. to provide a semi-quantitative assessment of the relative contribution from sea ice-associated $(F$. curta and $F$. cylindrus) and open water $(F$. kerguelensis) diatoms. (Armand et al., 2005; Crosta et al., 2005; Crosta et al., 2008). Thus, the ratio $(F$. curta $+F$. cylindrus $) / F$. kerguelensis was determined (Table 2).

\section{Results and discussion}

The identification and quantification of the various lipids and their degradation products are described here according to the individual lipid classes at each sampling location. The sequence of presentation is arranged so as to first provide sufficient evidence 
for the oxidation state of the lipids, in order that the variability in the ratio of $\mathrm{IPSO}_{25}$ (1)/HBI III (2) can then be put into context.

3.1. Lipids and their degradation products in water samples from west of the Dalton Iceberg Tongue

\subsubsection{Chlorophyll phytyl side-chain}

In addition to phytol (4), which mainly arises from the hydrolysis of the chlorophyll phytyl side-chain during alkaline hydrolysis, significant amounts of 3,7,11,15tetramethylhexadecanoic acid (phytanic acid) (5), 3,7,11,15-tetramethylhexadec-1-en-ol-3 (isophytol) (6) and 3-methylidene-7,11,15-trimethylhexadecan-1,2-diol (phytyldiol) (7) could also be detected in the different samples. However, phytanic acid (5) was not quantified in the present work due to its lack of specificity. Indeed, this isoprenoid acid is also formed during the aerobic and anaerobic bacterial degradation of phytol (Rontani and Volkman, 2003) and the grazing of phytoplankton (Prahl et al., 1984). In contrast, there have been very few reports of the presence of isophytol $(\mathbf{6})$ in the marine environment (Fang et al., 2006), so its relatively high proportion compared to phytol (1) in some samples (Table 1) is potentially surprising. Isophytol (6) may be formed in sediments either by enzyme-catalyzed allylic rearrangement during bacterial degradation of phytol under denitrifying conditions (Rontani et al., 1999), or by clay-catalyzed dehydration of phytol (de Leeuw et al., 1974). It is interesting to note that relatively high proportions of isophytol were also recently observed after $\mathrm{NaBH}_{4}$-reduction and alkaline hydrolysis of phytoplanktonic cells collected from Commonwealth Bay, Antarctica (Rontani and Galeron, 2016). In order to explain this observation, it was proposed that 
allylation (Berkessel, 2009) of the chlorophyll phytyl side-chain by peroxyl radicals could result in the formation of the precursor 3-peroxy-3,7,11,15-tetramethylhexadec-1-ene (8), with subsequent reduction to isophytol (6) (Fig. 2) (Rontani and Galeron, 2016). The absence of the initial reduction step employed here (i.e. using $\mathrm{NaBH}_{4}$ ) during conventional treatment of environmental samples is likely at the origin of the very few reports of isophytol (6) in previous studies. In any case, the high values of the ratio isophytol/phytol observed at station 25, and to a lesser extent at station 28B (Table 1), attest to the presence of high concentrations of peroxides, and thus of a strong photo- or autoxidation state of POM.

The formation of phytyldiol (7) results from initial Type II photosensitized oxidation (i.e. involving singlet oxygen $\left({ }^{1} \mathrm{O}_{2}\right)$ ) of the chlorophyll phytyl side-chain and subsequent hydrolysis of the photoproducts thus formed (Rontani et al., 1994). On the basis of its high specificity and widespread occurrence in the environment (Cuny and Rontani, 1999), this diol can be used as a specific tracer of chlorophyll photodegradation. Further, Cuny et al. (2002) proposed that the amount of chlorophyll photodegradation in the marine environment could be estimated from the so-called Chlorophyll Phytyl side-chain Photodegradation Index (CPPI) derived from the molar ratio phytyldiol/phytol. Using this approach, the highest photooxidation state of POM was confirmed as being at station 25 and the lowest at station $32(<1 \%$, not included in the figure) (Fig. 3).

\subsubsection{Sterols} (22-dehydrocholesterol) (10), cholest-5-en-3 $\beta$-ol (cholesterol) (11), 24-methylcholesta-

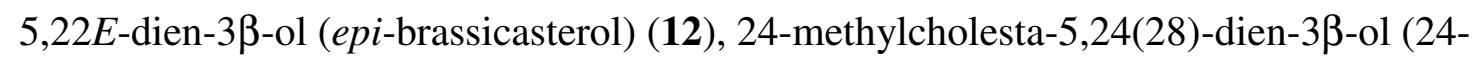
methylenecholesterol) (13) and 24-ethylcholest-7-en-3 $\beta$-ol (22-dihydrocondrillasterol) 

notably in Thalassiosira aff. antarctica (Rampen et al., 2007). Although cholesterol (11) may be derived from diatoms or Prymnesiophycean algae (Volkman, 1986), its dominance generally suggests an important contribution of zooplanktonic faecal material to the samples. Indeed, it is well known that zooplankton convert much of the sterols produced by algae into cholesterol (11) (Volkman et al., 1980; Prahl et al., 1984). Epi-brassicasterol (12) and 24-methylenecholesterol (13) are major constituents of several diatom species (Lee et al., 1980) including sea ice diatoms (Belt et al., 2018). However, it may be noted that epi-brassicasterol (12) is also present in some dinoflagellates and in many haptophytes (Volkman, 1986, 2003). The unusual sterol 22-dihydrochondrillasterol (14) was detected previously in some Chlorophyceae (Martin-Creuzburg et al., 2011; Martin-Creuzburg and Merkel, 2016). The sterol profiles observed in these samples (Supplementary Table 1) are thus typical of mixed assemblages of diatoms, Prymnesiophytes and Chlorophytes. hydroperoxides with low amounts of $\Delta^{4}-6 \alpha / \beta$-hydroperoxides (Smith, 1981). Here, we selected $\Delta^{4}-6 \alpha / \beta$-hydroperoxides as tracers of photooxidation of $\Delta^{5}$-sterols due to their high specificity and relative stability (Rontani et al., 2009; Christodoulou et al., 2009). These compounds were quantified after $\mathrm{NaBH}_{4}$ reduction to the corresponding diols and photooxidation percentage was obtained from the equation: photooxidation $\%=\left(\Delta^{4}\right.$-stera$6 \alpha / \beta$-diols $\% \times(1+0.3) / 0.3)$ (Christodoulou et al., 2009). The values obtained for epibrassicasterol (12) and 24-methylenecholesterol (13) (the two main algal sterols present in the samples analyzed) are shown in Fig. 3. Photooxidation of these two sterols exhibits the same general trend as that seen for chlorophyll, with the highest photooxidation state observed at station 25 (Fig. 3). Interestingly, as observed previously in the Arctic (Rontani et al., 2012; 2014a), photodegradation processes appeared to have acted more intensively 
on 24-methylenecholesterol (13) (mainly arising from diatoms) than on epi-brassicasterol (12) (arising from diatoms and/or Prymnesiophytes). These differences confirm the higher efficiency of Type II photosensitized oxidation processes in diatoms compared to Prymnesiophytes.

Stanols constitute useful indicators of bacterial degradation of $\Delta^{5}$-sterols (Gagosian et al., 1982; de Leeuw and Baas, 1986; Wakeham, 1989). We thus quantified the ratio 24methyl-5 $\alpha$-cholest-22E-en-3 $\beta$-ol (epi-brassicastanol) (15)/epi-brassicasterol (12) to indicate the extent of bacterial degradation of algal material. (Note: the ratio 24-methyl-

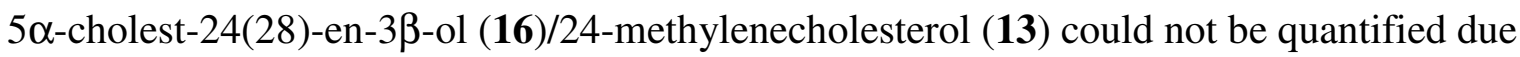
to co-elution of the stanol 16 with the isobaric campesterol (17)). The values of the ratio epi-brassicastanol (15)/epi-brassicasterol (12) (Table 1) show only a weak increase with depth suggesting that bacterial degradation processes acted only weakly on algal material.

\subsubsection{Fatty acids}

The fatty acid content of the SPM samples is characterized by a very low content of polyunsaturated fatty acids (PUFAs) and notably of $\mathrm{C}_{18: 4}(\mathbf{1 9}), \mathrm{C}_{20: 5}(\mathbf{2 0})$ and $\mathrm{C}_{22: 6}(\mathbf{2 1})$ acids, which are typical for marine plankton (Kattner et al., 1983). Instead, the dominant fatty acids are the saturated and monounsaturated fatty acids (MUFAs) (i.e. $\mathrm{C}_{14: 0}(\mathbf{2 2})$, $\mathrm{C}_{16: 1 \omega 7}$ (palmitoleic acid) (23), $\mathrm{C}_{16: 0}$ (palmitic acid) (24), $\mathrm{C}_{18: 1 \omega 9}$ (oleic acid) (25), $\mathrm{C}_{18: 1 \omega 7}$ (vaccenic acid) (26) and $\left.\mathrm{C}_{18: 0}(\mathbf{2 7})\right)$ (Supplementary Table 1). The reactivity of unsaturated fatty acids with respect to auto- and photooxidative processes increases, logically, with the number of double bonds (Frankel, 1998; Rontani et al., 1998). The very low amounts of PUFAs is therefore suggestive of intense photo- or autoxidation of the samples. In order to confirm this, the oxidation products of MUFAs (oleic and palmitoleic acids) (25 and 23) were quantified since they are sufficiently stable in the marine environment to act as 
markers of these abiotic degradative processes (Marchand and Rontani, 2001, 2003).

Photo- and autoxidation of monounsaturated fatty acids affords mixtures of isomeric allylic hydroperoxyacids (Frankel, 1998). Based on the specific formation of cis isomers by autoxidation (Porter et al., 1995), the relative importance of photooxidation and autoxidation can easily be distinguished by quantifying the respective hydroxyacids that result from $\mathrm{NaBH}_{4}$-reduction of these compounds (Marchand and Rontani, 2001). The results obtained (Fig. 4) show a clear difference in reactivity between palmitoleic (23) and oleic (25) acids. Indeed, photo- and autoxidation states appeared to be considerably higher in the case of palmitoleic acid (23) (the main MUFA of diatoms, Fahl and Kattner, 1993; Leu et al., 2010) compared to oleic acid (25) (dominant in Prymnesiophytes, Rossi et al., 2006). These outcomes are consistent with previous observations of more efficient photoand autoxidation processes in diatoms than in Prymnesiophytes (Rontani et al., 2012; 2014b). Such differences in reactivity were attributed previously to the involvement of intra-cellular compartmentalization effects, which may significantly modify the reactivity of lipids towards autoxidative and photooxidative processes according to their location in phytoplanktonic cells (Rontani, 2012).

The palmitoleic (23)/palmitic acid (24) ratio is often employed to follow diatom blooms (Pedersen et al., 1999; Reuss and Poulsen, 2002). Due to the strong oxidation of palmitoleic acid (23) observed in some of our samples (Fig. 4), we employed the ratio ( $\Sigma$ palmitoleic acid (23) and its oxidation products)/palmitic acid (24) to estimate the relative proportion of diatom in the mixed phytoplankton assemblages. Using this approach, we observed a relatively high proportion of (strongly oxidized) diatoms in the surface water sample of station 25 and an increase in their proportion with water depth at station $28 \mathrm{~B}$ 


\subsubsection{Cutin components}

Relatively high amounts of 9,16-dihydroxyhexadecanoic (29) and 10,16dihydroxyhexadecanoic (28) acids were observed in some samples (Table 1). These compounds are well-known depolymerisation products of cutins (insoluble polyester polymers) present in the outer layer of the epidermal cells of primary plant tissues, such as leaves) (Deas and Holloway, 1977; Kolattukudy, 1977, 1980). The presence of such compounds is very surprising since the Antarctic biome is an unfavorable environment for higher plant growth. Only two native phanerogams, Deschampsia antarctica Desv. and Colobanthus quitensis (Kunth) Bartl., occur in Antarctica to almost $69^{\circ} \mathrm{S}$ (Smith 1994). The high concentrations of dihydroxyacids $\mathbf{2 8}$ and $\mathbf{2 9}$ detected in some sub-surface water samples (Table 1) is therefore attributed to the accumulation of low density debris of such plants, probably resulting from inflow of near-surface water masses carrying terrestrial material. In contrast, the occurrence of these compounds due to sediment resuspension seems unlikely due to their absence in the deeper water column samples.

\subsubsection{HBI alkenes}

The two HBI lipids, IPSO $_{25}$ (1) and HBI III (2), reported previously by Smik et al. (2016) in the surface water samples described here, were also present in each of the subsurface and deep water samples investigated for the first time within the current study. Although there was some variability in the absolute and relative concentrations of these HBIs between the surface and sub-surface samples, The $\mathrm{IPSO}_{25}(\mathbf{1}) / \mathrm{HBI}$ III (2) ratio was mainly slightly higher in the majority of the sub-surface samples compared to the surface water counterparts, with CTD-004 and -014 the only exceptions. More striking changes to this ratio were observed with the corresponding deep water samples, however, with mean 

when compared with the surface and sub-surface samples, respectively (Table 1).

The systematic increase of the ratio $\mathbf{1 / 2}$ with depth (Table 1) may potentially be attributed to: (i) a relatively higher contribution of ice algae (and thus $\operatorname{IPSO}_{25}(\mathbf{1})$ ) to the deeper samples resulting from their stronger aggregation and therefore higher sinking rate, or (ii) a stronger abiotic degradation of HBI III (2) during settling through the water column. One characteristic of sea ice algae is their ability to produce high amounts of extracellular polymeric substances (EPS); the production of which facilitates the attachment of algae to their substrate (sea ice) but also allows the formation of aggregates of algal cells (Riebesell, 1991; Alldredge et al., 1993; Passow, 2002), thus shortening their residence time within the euphotic zone. In the case of station $28 \mathrm{~B}$, the simultaneous increase of the ratios $\mathbf{1} / \mathbf{2}$ and ( $\Sigma$ palmitoleic acid (23) and its oxidation products)/palmitic acid (24) with depth (Table 1) suggests a dominance of aggregated ice diatom material in the deepest SPM sample.

Photo- and autoxidation of $\operatorname{IPSO}_{25}(\mathbf{1})$ were previously studied in vitro (Rontani et al., 2011; 2014a). Based on its very low degradation rates (resulting from the poor reactivity of its two terminal double bonds (i.e. at C6-17 and C23-24) towards ${ }^{1} \mathrm{O}_{2}$ and free radicals), it is feasible that this diene (1) could be largely unaffected by abiotic oxidation within the water column of the oceans, at least in comparison with some more unsaturated lipids, or those containing more reactive double bonds. Indeed, HBI III (2) possesses two tri-substituted double bonds (i.e. at C7-20 and C9-10), both of which are more reactive towards ${ }^{1} \mathrm{O}_{2}$ (Frimer, 1983) than the two double bonds in $\mathrm{IPSO}_{25}$. In addition, the relative positions of these two double bonds in HBI III (2) creates a bis-allylic methylene group (at C-8) that can lose a hydrogen atom even more readily (Yin et al., 2011). HBI III (2) is thus very sensitive towards photo- and autoxidation processes and exhibits degradation rates 
close to those of PUFAs (Rontani et al., 2014a). On the basis of the very intense abiotic alteration of these fatty acids in the samples investigated here (see section 3.1.3), a similar oxidation of HBI III (2) was thus expected. However, we were not able to detect the previously identified primary oxidation products of HBI III (2) (Rontani et al., 2014a), probably due to their further oxidation to polar and oligomeric compounds, which are not generally detectable using the GC-MS methods employed here. This conclusion is consistent with the strong photo- and autoxidation states of palmitoleic acid (23) observed III/kauto palmitoleic acid $>10)$ (Rontani et al., 2011; 2014a).

In order to provide further evidence for the influence of autoxidative processes upon the ratio $\mathbf{1 / 2}$, we measured it, together with the autoxidation state of sitosterol (42) (estimated on the basis of $3 \beta, 5 \alpha, 6 \beta$-trihydroxysitosterol (43) as previously proposed by Christodoulou et al. (2009)) and palmitoleic acid (23) in the water column samples from (MC45 and MC61; Fig. 1), with one of these (MC61) located directly at the station where the CTD015 samples were taken. The ratio $\mathbf{1 / 2}$ was also measured in the surface waters recovered from the top of the MC61 sediment core and in the suspension of diatomaceous 'fluff' taken at the water-sediment interface, thereby providing a near-continuous depth sequence from surface waters to underlying sediments. Although sitosterol (42) is commonly associated with higher plants ((Lütjohann, 2004), it is also present in phytoplankton, and notably in diatoms (Volkman, 1986; 2003). Due to the absence of lipid signatures of terrestrial material in the water samples collected at station 32 and in the sediments from nearby locations, the presence of sitosterol (42) in these samples was thus attributed to an algal origin. The results obtained (Table 2) show a clear increase in both 
the ratio $1 / 2$ and the autoxidation state of algal material with water depth and then into the surface sediments (Table 2). The failure to detect oxidation products of sitosterol in the water column samples is attributed to the relatively poor chromatographic properties of the only partially silylated (at positions 3 and 6) triol 43, which hinders its detection at low concentrations.

Although we do not currently have detailed taxonomic data from all sampling stations/types, we do have data from the station for which we have lipid profiles from both the water column and underlying Megacore (viz. CTD015 \& MC61). The most striking feature is the consistent decrease in the ratio $(F$. curta $+F$. cylindrus $) / F$. kerguelensis through the water column, the water-sediment interface and then into the sub-surface sediment (Table 2), suggesting a progressive decrease in the relative contribution of sea ice-associated and open-water diatoms. However, this conclusion is contrary to what might the latter, at some locations, are determined more by the enhanced degradation of HBI III (2)(relative to $\mathrm{IPSO}_{25}$ ) as shown from the lipid data described above; the caveat being that the aforementioned Fragilariopsis spp. are not known HBI-producers. We also assume that the water column data derived from samples taken in a single sampling season are also representative of multi-annual accumulation that the sediment samples likely reflect. Unfortunately, the known sources of IPSO $_{25}$ and HBI III (2) were of too low abundance for more direct comparisons between lipid and taxonomic distributions to be made for these samples. Interestingly, a positive relationship between $\operatorname{IPSO}_{25}(\mathbf{1}) / \mathrm{HBI}$ III (2) and the ratio F. curta/F. kerguelensis (i.e., a slight modification to our diatom ratio) was reported in a previous downcore sediment study from the region (Massé et al., 2011), suggesting that the modifications to the former described herein for the water column and water-sediment interface may not necessarily have an adverse impact on its use as a proxy measure of sea 
ice change in palaeo records, especially for qualitative purposes. Further studies comparing these two approaches will, however, be required, before the generality of this observation can be confirmed, and the most reliable use of $\mathrm{IPSO}_{25} / \mathrm{HBI}$ III as a proxy measure of sea ice change can be deciphered.

\subsection{Phytoplanktonic material from Commonwealth Bay (East Antarctica)}

To demonstrate the efficiency of photo- and autoxidation processes on HBI III (2) in this region, more generally, we also analysed phytoplanktonic cells collected from surface waters of Commonwealth Bay (also East Antarctica; see Fig. 1). In this weakly oxidized material (oxidation percentage of palmitoleic acid $(\mathbf{2 3})<5 \%$ ), MRM analyses allowed us to detect the HBI alcohols 44-48 (Figs. 5B and 6B, Table 3). The assignment of these compounds was confirmed by comparison with the MRM chromatograms of standards obtained by photo- and autoxidation of HBI III (2) (Figs. 5A and 6A) (Rontani et al., 2014b). Alcohol 48 is produced specifically by photooxidation of HBI III (2), while alcohols 44-47 result from both its photo- and autoxidation (Rontani et al., 2014a). On the basis of the detection of these oxidation products in a weakly oxidized phytoplanktonic sample from Commonwealth Bay, the strong increase of the ratio $\mathrm{IPSO}_{25}$ (1)/HBI III (2) observed in the deeper SPM samples from stations 25, 27, 32 and 34 and in near-surface sediments from the polynya region west of the Dalton Iceberg Tongue (Tables 1 and 2) may be thus attributed to an intense photo- and/or autoxidation of HBI III (2) within the water column, with further autoxidation of HBI III (2), relative to $\operatorname{IPSO}_{25}(\mathbf{1})$, at the watersediment interface and in the oxic layer of the underlying sediment.

During the $\mathrm{NaBH}_{4}$-reduction step employed to avoid thermal degradation of hydroperoxides during the subsequent saponification reaction, the sum of hydroperoxides and their degradation products (alcohols and ketones) was obtained via quantification of 
their respective alcohols. Two different treatments were employed (acetylation and saponification $v s \mathrm{NaBD}_{4}$-reduction and saponification) (see Section 2.2) in order to specifically quantify hydroperoxides and their main degradation products (i.e. alcohols and ketones). The results obtained (summarized in Table 4) show that a substantial proportion (ca. 55-81\%) of HBI III (2) oxidation products were still present as hydroperoxides. Interestingly, the decrease in unlabeled phytol (4) concentration (5-20\%) observed when the treatment of phytoplanktonic cells involved acetylation and saponification instead of $\mathrm{NaBD}_{4}$-reduction and saponification, provides further evidence for the formation pathway of isophytol (6) proposed previously (Rontani and Galeron, 2016) (Fig. 2). Indeed, this decrease likely results from the presence of 1-peroxy-3,7,11,15tetramethylhexadec-3-ene (9), which is formed by allylic rearrangement of its isomer $\mathbf{8}$ (Fig. 2).

561

\section{Conclusions}

Selected lipids and their oxidation products were quantified in SPM samples collected at different water depths in the polynya region west of the Dalton Iceberg Tongue (East Antarctica). The sterol profiles were typical of mixed assemblages of diatoms, prymnesiophytes and chlorophytes. Surprisingly, some samples contained depolymerisation products of cutins, the presence of which was attributed to the accumulation of low-density debris of the two phanerogams present in Antarctica.

We identified an intense photo- and autoxidation of unsaturated diatom components (e.g. palmitoleic acid (23), 24-methylenecholesterol (13), chlorophyll phytyl side-chain

571 (4)), but not of HBI III (2), despite its known reactivity towards such processes, likely due to its susceptibility towards further oxidation. However, oxidation products of HBI III (2) 
could be detected in weakly oxidized SPM samples collected from Commonwealth Bay

574 (East Antarctica), clearly demonstrating the oxidation of this lipid in this region.

The systematic increase of the ratio $\operatorname{IPSO}_{25}(\mathbf{1}) / \mathrm{HBI}$ III (2) observed with depth in the water column and in some underlying sediments thus appears to result, in part, from an intense and preferential abiotic degradation of the HBI III (2) due to a combination of photo- and autoxidation processes (Fig. 7). At one sampling site, the increase in the $\mathrm{IPSO}_{25}$ (1)/HBI III (2) ratio with depth was opposite to that of the ratio of selected sea iceassociated versus open-water diatoms, suggesting that the differential biomarker degradation was a dominant factor. However, for another sampling site, the increase in the $\mathrm{IPSO}_{25}(\mathbf{1}) / \mathrm{HBI}$ III (2) ratio appeared to be more influenced by the accumulation of ice algal material, although we do not yet have the complementary taxonomic data to confirm this.

Distinguishing between these two factors will require more detailed and combined lipid and taxonomic analysis in the future. In the meantime, it is evident from the results presented here, that the differential degradation of $\operatorname{IPSO}_{25}(\mathbf{1})$ and HBI III (2) in the water column and in near-surface sediments (at least) can impact on the ratio between these two HBIs between their source and sedimentary environments. The latter should be taken into account when using this parameter for palaeo sea ice reconstruction purposes in the Antarctic. The extent to which the $\mathrm{IPSO}_{25}$ (1)/HBI III (2) ratio reflects established proxy measures of past sea ice change (e.g., the ratio of certain Fragilariopsis spp. as described herein) will require more studies of both parameters in further downcore records from the $594 \quad$ Antarctic. 

apparatus employed. Thanks are due to the scientific party and crew of cruise NBP1402; the project (P.I. A. Leventer) was funded by NSF ANT-1143836. We also thank G. Massé

601 for the donation of the phytoplankton samples collected in the Commonwealth Bay during the IPEV-COCA2012 cruise funded by IPEV (1010-ICELIPIDS program) and ANR (CLIMICE program). We thank two anonymous referees for their useful and constructive comments.

605

606

\section{References}

607

Alldredge, A.L., Passow, U., Logan, B.E., 1993. The abundance and significance of a class of large, transparent organic particles in the ocean. Deep-Sea Research Part IOceanographic Research Papers 40, 1131-1140.

Armand, L., Crosta, X., Romero, O., Pichon, J.J., 2005. The biogeography of major diatom taxa in Southern Ocean sediments.1. Sea ice related species. Palaeogeography, Palaeoclimatology, Palaeoecology 223, 93-126.

Armand, L.K., Ferry, A., Leventer, A., 2017. Advances in palaeo sea ice estimation. In: Thomas, D.N. (Ed.), Sea Ice. John Wiley \& Sons Ltd, Chichester, pp. 600-629.

Barbara, L., Crosta, X., Massé, G., Ther, O., 2010. Deglacial environments in eastern Prydz Bay, East Antarctica. Quaternary Science Reviews 29, 2731-2740. for major changes in sea ice conditions prior the instrumental period in Antarctic Peninsula. Quaternary Science Reviews 79, 99-110. 
Barbara, L., Crosta, X., Leventer, A., Schmidt, S., Etourneau, J., Domack, E., Massé, G., 2016. Environmental responses of the Northeast Antarctic Peninsula to the Holocene climate variability, Paleoceanography, 31, 131-147.

Belt, S.T., Cooke, D.A., Robert, J.-M., Rowland, S.J., 1996. Structural characterisation of widespread polyunsaturated isoprenoid biomarkers: $\mathrm{A} \mathrm{C}_{25}$ triene, tetraene and pentaene from the diatom Haslea ostrearia Simonsen. Tetrahedron Letters 37, 4755-4758.

Belt, S.T., Allard, W.G., Massé, G., Robert, J.-M., Rowland, S.J., 2000. Highly branched isoprenoids (HBIs): identification of the most common and abundant sedimentary isomers. Geochimica et Cosmochimica Acta 64, 3839-3851.

Belt, S.T., Massé, G., Rowland, S.J., Poulin, M., Michel, C., LeBlanc, B., 2007. A novel chemical fossil of palaeo sea ice: $\mathrm{IP}_{25}$. Organic Geochemistry 38, 16-27.

Belt, S.T., Müller, J., 2013. The Arctic sea ice biomarker IP25: a review of current understanding, recommendations for future research and applications in palaeo sea ice reconstructions. Quaternary Science Reviews 79, 9-25.

Belt, S.T., Brown, T.A., Ampel, L., Cabedo-Sanz, P., Fahl, K., Kocis, J.J., Masse, G., Navarro-Rodriguez, A., Ruan, J., Xu, Y., 2014. An inter-laboratory investigation of the Arctic sea ice biomarker proxy $\mathrm{IP}_{25}$ in marine sediments: key outcomes and recommendations. Climate of the Past 10, 155-166.

Belt, S.T., Cabedo-Sanz, P., Smik, L., Navarro-Rodriguez, A., Berben, S.M.P., Knies, J., Husum, K., 2015. Identification of paleo Arctic winter sea ice limits and the marginal ice zone: Optimised biomarker-based reconstructions of late Quaternary Arctic sea ice. Earth and Planetary Science Letters 431, 127-139.

Belt, S.T., Smik, L., Brown, T.A., Kim, J.H., Rowland, S.J., Allen, C.S., Gal, J.K., Shin, K.H., Lee, J.I., Taylor, K.W.R., 2016. Source identification and distribution reveals 
the potential of the geochemical Antarctic sea ice proxy $\operatorname{IPSO}_{25}$. Nature Communications 7, 12655.

647

648

649

650

651

652

653

654

655

656

657

658

659

660

661

662

663

664

665

666

667

668

Belt, S.T., Brown, T.A., Smik, L., Assmy, P., Mundy, C.J., 2018. Sterol identification in floating Arctic sea ice algal aggregates and the Antarctic sea ice diatom Berkeleya adeliensis. Organic Geochemistry 118, 1-3.

Belt, S.T., 2018. Source-specific biomarkers as proxies for Arctic and Antarctic sea ice. Organic Geochemistry 125, 273-295.

Berkessel, A., 2014. Science of Synthesis: Houben-Weyl Methods of Molecular Transformations, Vol. 38: Peroxides, Georg Thieme Verlag, p. 75.

Brown, T.A., Belt, S.T., Tatarek, A., Mundy, C.J., 2014c. Source identification of the Arctic sea ice proxy $\mathrm{IP}_{25}$. Nature Communications 5, 4197.

Campagne, P., Costa, X., Houssais, M.N., Swingedouw, D., Schmidt, S., Martin, A., Devred, E., Capo, S., Marieu, V., Closset, I., Massé, G., 2015 Glacial ice and atmospheric forcing on the Mertz Glacier Polynya over the past 250 years. Nature Communications 6, 6642.

Campagne, P., Crosta, X., Schmidt, S., Houssais, M.N., Ther, O., Massé, G., 2016. Sedimentary response to sea ice and atmospheric variability over the instrumental period off Adélie Land, East Antarctica. Biogeosciences 13, 4205-4218.

Christodoulou S., Marty J.-C., Miquel J.-C., Volkman J.K., Rontani J.-F., 2009. Use of lipids and their degradation products as biomarkers for carbon cycling in the northwestern Mediterranean Sea. Marine Chemistry 113, 25-40.

Collins, L.G., Allen, C.S., Pike, J., Hodgson, D.A., Weckström, K., Massé, G., 2013. Evaluating highly branched isoprenoid (HBI) biomarkers as a novel Antarctic sea-ice proxy in deep ocean glacial age sediments. Quaternary Science Reviews 79, 87-98. 
Crosta, X., Koc, N., 2007. Diatoms: From micropaleontology to isotope geochemistry, in: Methods in Late Cenozoic Paleoceanography, Hilaire-Marcel, C. and de Vernal, A. (Eds.), Elsevier, Amsterdam, the Netherlands, pp. 327-369.

Crosta, X., Romero, O., Armand, L., Pichon, J.J., 2005. The biogeography of major diatom taxa in Southern Ocean sediments. 2. Open Ocean related species. Palaeogeography, Palaeoclimatology, Palaeoecology 223, 66-92.

Crosta, X., Denis, D., Ther, O., 2008. Sea ice seasonality during the Holocene, Adelie Land, East Antarctica. Marine Micropaleontology 66, 222-232.

Cuny, P., Rontani, J.-F., 1999. On the widespread occurrence of 3-methylidene-7,11,15trimethylhexadecan-1,2-diol in the marine environment: a specific isoprenoid marker of chlorophyll photodegradation. Marine Chemistry 65, 155-165.

Cuny, P., Marty, J.-C., Chiaverini, J., Vescovali, I., Raphel, D., Rontani, J.-F., 2002. Oneyear seasonal survey of the chlorophyll photodegradation process in the Northwestern Mediterranean Sea. Deep-Sea Research II 49, 1987-2005.

Deas, A.H.B., Holloway, P.J., 1977. The intermolecular structure of some plant cutins. In: Tevini, M., Lichtenthaler, H. (Eds.), Lipids and Lipid Polymers in Higher Plants. Springer, Berlin, pp. 293-299.

Denis, D., Crosta, X., Barbara, L., Massé, G., Renssen, H., Ther, O., Giraudeau, J., 2010. Sea ice and wind variability during the Holocene in East Antarctica: insight on middle-high latitude coupling. Quaternary Science Reviews 29, 3709-3719. de Leeuw, J.W., Correia, V.A., Schenck, P.A., 1974. On the decomposition of phytol under simulated geological conditions and in the top-layer of natural sediments. In: Tissot, B., Bienner, F. (Eds.), Advances in Organic Geochemistry 1973. Editions Technip, Paris, pp. 993-1004. 
de Leeuw, J.W., Baas, M., 1986. Early-stage diagenesis of steroids. In: Johns, R.B. (Ed.), Biological Markers in the Sedimentary Record. Elsevier, Amsterdam, pp. 101-123. de Vernal, A., Gersonde, R., Goosse, H., Seidenkrantz, M.-S., Wolff, E.W., 2013. Sea ice in the paleoclimate system: the challenge of reconstructing sea ice from proxies - an introduction. Quaternary Science Reviews 79, 1-8.

Dickson, R., Rudels, B., Dye, S., Karcher, M., Meincke, J., Yashayaev, I., 2007. Current estimates of freshwater flux through Arctic and subarctic seas. Progress in Oceanography 73, 210-230.

Etourneau, J., Collins, L.G., Willmott, V., Kim, J.H., Barbara, L., Leventer, A., Schouten, S., Sinninghe Damsté, J.S., Bianchini, A., Klein, V., Crosta, X., Massé, G., 2013. Holocene climate variations in the western Antarctic Peninsula: evidence for sea ice extent predominantly controlled by changes in insolation and ENSO variability. Climate of the Past 9, 1431-1446.

Fahl, K., Kattner, G., 1993. Lipid content and fatty acid composition of algal communities in sea-ice and water from Weddell Sea (Antarctica). Polar Biology 13, 405-409.

Fang, J., Chan, O., Joeckel, R.M., Huang, Y., Wang, Y., Bazylinski, D.A., Moorman, T.B., Ang Clement, B.J., 2006. Biomarker analysis of microbial diversity in sediments of a saline groundwater seep of Salt Basin, Nebraska. Organic Geochemistry 37, 912-931. Fetterer F., Knowles K., Meier W.N., Savoie M., 2016. Sea Ice Index. ver.2 NSIDC: National Snow and Ice Data Center. Boulder, Colorado (https://doi.org/10.7265/N5736NV7) [Digital Media, updated daily]. IPCC, 2013: Summary for Policymakers. In: Climate Change 2013: The Physical Science Basis. Contribution of Working Group I to the Fifth Assessment Report of the Intergovernmental Panel on Climate Change [Stocker, T.F., D. Qin, G.-K. Plattner, M. 
Tignor, S.K. Allen, J. Boschung, A. Nauels, Y. Xia, V. Bex and P.M. Midgley (eds.)]. Cambridge University Press, Cambridge, United Kingdom and New York, NY, USA. Frankel, E.N., 1998. Lipid Oxidation. The Oily Press, Dundee.

Frimer, A.A., 1979. The reaction of singlet oxygen with olefins: the question of mechanism. Chemical Review 79, 359-387.

Gagosian, R.B., Smith, S.O., Nigrelli, G.E., 1982. Vertical transport of steroid alcohols and ketones measured in a sediment trap experiment in the equatorial Atlantic Ocean. Geochimica et Cosmochimica Acta 46, 1163-1172.

Hasle, G.R., 1965. Nitzschia and Fragilariopsis species studied in the light and electron microscopes III. The genus Fragilariopsis. Skr. Norske Vidensk-Akad. I. Mat.-Nat. K1. Ny Serie 21, 1-49.

Holland, H.L., Diakow, P.R.P., 1979. Microbial hydroxylation of steroids. 5. Metabolism of androst-5-en-3,17-dione and related compounds by Rhizopus arrhizus ATCC 11145. Canadian Journal of Chemistry 57, 436-440.

Johns, L., Wraige, E.J., Belt, S.T., Lewis, C.A., Massé, G., Robert, J.M., Rowland, S.J., 1999. Identification of a $\mathrm{C}_{25}$ highly branched isoprenoid (HBI) diene in Antarctic sediments, Antarctic sea-ice diatoms and cultured diatoms. Organic Geochemistry 30, $1471-1475$.

Kattner, G., Cercken, G., Eberlein, K., 1983. Development of lipid during a spring bloom in the northern North Sea. I. Particulate fatty aclds. Marine Chemistry 14, 149-162.

Kim, S.Y., Choi, J.K., Dolan, J.R., Shin, H.C., Lee, S., Yang, E.J., 2013. Morphological and ribosomal DNA-based characterization of six Antarctic ciliate morphospecies from the Amundsen Sea with phylogenetic analyses. Journal of Eukaryotic Microbiology 60, 497-513. 
Kolattukudy, P.E., 1977. Lipid polymers and associated phenols, their chemistry, biosynthesis, and role in pathogenesis, Recent Advances in Phytochemistry 77, 185246.

Kolattukudy, P.E., 1980. Cutin, suberin and waxes. In: Stumpf, P.K., Conn, E.E. (Eds.), The Biochemistry of Plants, vol. 4. Academic Press, Davis, pp. 571-645.

Lee, C., Gagosian, R.B., Farrington, J.W., 1980. Geochemistry of sterols in sediments from Black Sea and the southwest African shelf and slope, Organic Geochemistry 2, 103113.

Leventer, A., 2013. The fate of Antarctic "sea ice diatoms" and their use as paleoenvironmental indicators. In: Lizotte, M.P., Arrigo, K.R. (Eds.), Antarctic Sea Ice: Biological processes, Interactions and Variability. American Geophysical Union, pp. 121-137.

Leventer, A., Armand, L., Harwood, D.M., Jordan, R., Ligowski, R., 2008. New approaches and progress in the use of polar marine diatoms in reconstructing sea ice distribution. Papers in the Earth and Atmospheric Sciences. Paper 287.

Leventer, A., 1998. The fate of sea ice diatoms and their use as paleoenvironmental indicators. In: Lizotte, M.P. and Arrigo, K.R. (Eds.), Antarctic Sea Ice: Biological Processes, AGU Research Series 73, Washington, D.C., pp. 121-137.

Leu, E., Wiktor, J., Soreide, J.E., Berge, J., Falk-Petersen, S., 2010. Increased irradiance reduces food quality of sea ice algae. Marine Ecology Progress Series 411, 49-60.

Loidl-Stahlhofen, A., Spiteller, G., 1994. $\alpha$-Hydroxyaldehydes, products of lipid peroxidation. Biochimica et Biophysica Acta 1211, 156-160.

Lütjohann, D., 2004. Sterol autoxidation: from phytosterols to oxyphytosterols. British Journal of Nutrition 91, 3-4. 
Marchand, D., Rontani, J.-F., 2001. Characterisation of photooxidation and autoxidation products of phytoplanktonic monounsaturated fatty acids in marine particulate matter and recent sediments. Organic Geochemistry 32, 287-304.

Marchand, D., Rontani, J.-F., 2003. Visible light-induced oxidation of lipid components of purple sulfur bacteria: a significant process in microbial mats. Organic Geochemistry $34,61-79$.

Martin-Creuzburg, D., Beck, B., Freese, H.M., 2011. Food quality of heterotrophic bacteria for Daphnia magna: evidence for a limitation by sterols. FEMS Microbiology 76, $592-601$.

Martin-Creuzburg, D., Merkel, P., 2016. Sterols of freshwater microalgae: potential implications for zooplankton nutrition. Journal of Plankton Research 38, 865-877.

Mihara, S., Tateba, H., 1986. Photosensitized oxygenation reactions of phytol and its derivatives. The Journal of Organic Chemistry 51, 1142-1144.

Passow, U., 2002. Transparent exopolymer particles (TEP) in aquatic environments. Progress in Oceanography 55, 287-333.

Pedersen, L., Jensen, H.M., Burmeister, A.D., Hansen, B.W., 1999. The significance of food web structure for the condition and tracer lipid content of juvenile snail fish (Pisces: Liparis spp.) along 65-728N off West Greenland. Journal of Plankton Research 21, 1593-1611.

Perette, M., Yool, A, Quartly, G.D., Popova, E.E., 2011. Near-ubiquity of ice-edge blooms in the Arctic. Biogeosciences 8, 515-524.

Porter, N.A., Caldwell, S.E., Mills, K.A., 1995. Mechanisms of free radical oxidation of unsaturated lipids. Lipids 30, 277-290. 

in plant lipids during passage through the gut of Calanus. Journal of the Marine Biological Association of the United Kkingdom 64, 317-334.

Reuss, N., Poulsen, L.K., 2002. Evaluation of fatty acids as biomarkers for a natural plankton community. A field study of a spring bloom and a post-bloom period off West Greenland. Marine Biology 141, 423-434.

Riebesell U., Schloss I., Smetacek V., 1991. Aggregation of algae released from melting sea ice-implications for seeding and sedimentation. Polar Biology 11,239-248.

Rampen, S.W., Abbas, B.A., Schouten, S., Sinninghe Damsté, J.S., 2010. A comprehensive study of sterols in marine diatoms (Bacillariophyta): implications for their use as tracers for diatom productivity. Limnology and Oceanography 55, 91-105.

Rontani, J.-F., Grossi, V., Faure, F., Aubert, C., 1994. “'Bound”' 3-methylidene-7,11,15trimethylhexadecan-1,2-diol: a new isoprenoid marker for the photodegradation of chlorophyll-a in seawater. Organic Geochemistry 21, 135-142.

Rontani, J.-F., Cuny, P., Grossi, V., 1998. Identification of a pool of lipid photoproducts in senescent phytoplanktonic cells. Organic Geochemistry 29, 1215-1225.

Rontani, J.-F., Bonin, P., Volkman, J.K., 1999. Biodegradation of free phytol by bacterial communities isolated from marine sediments under aerobic and denitrifying conditions. Applied and Environmental Microbiology 65, 5484-5492.

Rontani, J.-F., Volkman, J.K., 2003. Phytol degradation products as biogeochemical tracers in aquatic environments. Organic Geochemistry 34, 1-35.

Rontani, J.-F., Aubert, C., 2005. Characterization of isomeric allylic diols resulting from chlorophyll phytyl side chain photo- and autoxidation by electron ionization gas chromatography/mass spectrometry. Rapid Communications in Mass Spectrometry 19, 637-646. 
Rontani, J.-F., Zabeti, N., Wakeham, S.G., 2009. The fate of marine lipids: Biotic vs. abiotic degradation of particulate sterols and alkenones in the Northwestern Mediterranean Sea. Marine Chemistry 113, 9-18.

Rontani, J.-F., Belt, S.T., Vaultier, F., Brown, T.A., 2011. Visible light-induced photooxidation of highly branched isoprenoid (HBI) alkenes: a significant dependence on the number and nature of the double bonds. Organic Geochemistry 42, 812-822.

Rontani, J.-F., 2012. Photo- and free radical-mediated oxidation of lipid components during the senescence of phototrophic organisms. In: T. Nagata Ed., Senescence. Intech, Rijeka, pp. 3-31.

Rontani, J.-F., Charriere, B., Forest, A., Heussner, S., Vaultier, F., Petit, M., Delsaut, N., Fortier, L., Sempéré, R., 2012. Intense photooxidative degradation of planktonic and bacterial lipids in sinking particles collected with sediment traps across the Canadian Beaufort Shelf (Arctic Ocean). Biogeosciences 9, 4787-4802.

Rontani, J.-F., Charrière, B., Sempéré, R., Doxaran, D., Vaultier, F., Vonk, J.E., Volkman, J.K., 2014a. Degradation of sterols and terrigenous organic matter in waters of the Mackenzie Shelf, Canadian Arctic. Organic Geochemistry 75, 61-73.

Rontani, J.-F., Belt, S., Vaultier, F., Brown, T., Massé, G., 2014b. Autoxidative and photooxidative reactivity of highly branched isoprenoid (HBI) alkenes. Lipids, 49(5), 481-494.

Rontani, J.-F., Galeron, M.-A., 2016. Autoxidation of chlorophyll phytyl side-chain in senescent phototrophic organisms: a potential source of isophytol in the environment. Organic Geochemistry 97, 37-40.

Rontani, J.-F., Amiraux, R., Lalande, C., Babin, M., Kim, H.-R., Belt, S.T., 2018. Use of palmitoleic acid and its oxidation products for monitoring the degradation of ice algae in Arctic waters and bottom sediments. Organic Geochemistry 124, 88-102. 
Rossi, S., Sabates, A., Latasa, M., reyes, E., 2006. Lipid biomarkers and trophic linkages between phytoplankton, zooplankton and anchovy (Engraulis encrasicolus) larvae in the NW Mediterranean. Journal of Plankton Research 28, 551-562.

Sakshaug, E., Johnsen, G., Kristiansen, S., von Quillfeldt, C., Rey, F., Slagstad, D., Thingstad, F., 2009. Phytoplankton and primary production. In: Sakshaug, E., Johnsen, G., Kovacs, K. (Eds), Ecosystem Barents Sea. Tapir Academic Press, Trondheim, pp.167-208.

Scherer, R.P., 1994. A new method for the determination of absolute abundance of diatoms and other silt-sized sedimentary particles. Journal of Paleolimnology 12 (1), 171-178.

Schmidt, K., Brown, T.A., Belt, S.T., Ireland, L.C., Taylor, K.W.R., Thorpe, S.E., Ward, P., Atkinson, A., 2018. Do pelagic grazers benefit from sea ice? Insights from the Antarctic sea ice proxy IPSO 25 . Biogeosciences 15, 1987- 2006.

Schrader, H.J., Gersonde, R., 1978. Diatoms and silicoflagellates. In: Zachariasse, A. (Ed.), Micropaleontological Counting Methods and Techniques - An Exercise on Eight Meters Section of the Lower Pliocene of Capo Rossello, Sicily. Utrecht Micropaleontology Bulletin, 17, pp. 129-176.

Scott, F., Marchant, H.J., 2005. Antarctic Marine Protists 1st ed. F. Scott and H. J. Marchant, eds., Canberra, Hobart: Australian Biological Resources Study and Australian Antarctic Division.

Serreze, M.C., Stroeve, J., Barrett, A.P., Boisvert, L.N., 2016. Summer atmospheric circulation anomalies over the Arctic Ocean and their influence on September sea ice extent. A cautionary tale. Journal of Geophysical Research: Atmospheres 121, $11463-$ 11485.

Smik, L., Belt, S.T., Lieser, J.L., Armand, L.K., Leventer, A., 2016. Distributions of highly branched isoprenoid alkenes and other algal lipids in surface waters from East 
Antarctica: Further insights for biomarker-based paleo sea-ice reconstruction. Organic Geochemistry 95, 71-80.

Smith, L.L., 1981. The autoxidation of cholesterol. Plenum Press, New York, pp. 119-132. Smith, R.I.L., 1994. Vascular plants as bioindicators of regional warming in Antarctica. Oecologia 99, 322-328.

Smith, W.O., 1987. Phytoplankton dynamics in marginal ice zones. Oceanography and Marine Biology 25, 11-38.

Smith, W.O., Jr., Nelson, D.M., 1986. The importance of ice-edge blooms in the Southern Ocean. Biosciences 36, 251-257.

Stroeve, J.C., Serreze, M.C., Holland, M.M., Kay, J.E., Malanik, J., Barrett, A.P., 2012. The Arctic's rapidly shrinking sea ice cover: a research synthesis. Climate Change $110,1005-1027$.

Thomas, D.N., 2017. Sea ice $3^{\text {rd }}$ ed. Wiley-Blackwell: pp 664.

Tomas, C.R., 1997. Identifying marine phytoplankton, San Diego: Academic Press.

Utermöhl, H., 1958. Zur Vervollkommnung der quantitativen Phytoplankton-Methodik. Internationale Vereinigung für theoretische und angewandte Limnologie: Mitteilungen $9,1-38$.

Volkman, J.K., Corner, E.D.S., Eglinton, G., 1980. Transformations of biolipids in the marine food web and in underlying bottom sediments, Colloque International du Centre National de la Recherche Scientifique 293, 185-197.

Volkman, J.K., 1986. A review of sterol markers for marine and terrigenous organic matter. Organic Geochemistry 9, 83-99.

Volkman, J.K., 2003. Sterols in microorganisms. Applied Microbiology and Biotechnology 60, 495-506. 
887 Walsh, J.E., Fetterer, F., Scott Stewart, J., Chapman, W.L., 2017. A database for depicting 888 Arctic sea ice variations back to 1850. Geographical Review 107, 89-107.

889 Wakeham, S.G., 1989. Reduction of stenols to stanols in particulate matter at oxic-anoxic 890 boundaries in seawater. Nature 342, 787-790.

891 Yin, H., Xu, L., Porter, N.A., 2011. Free radical lipid peroxidation: mechanisms and 892 analysis. Chemical Review 111, 5944-5972.

893 


\section{APPENDIX}

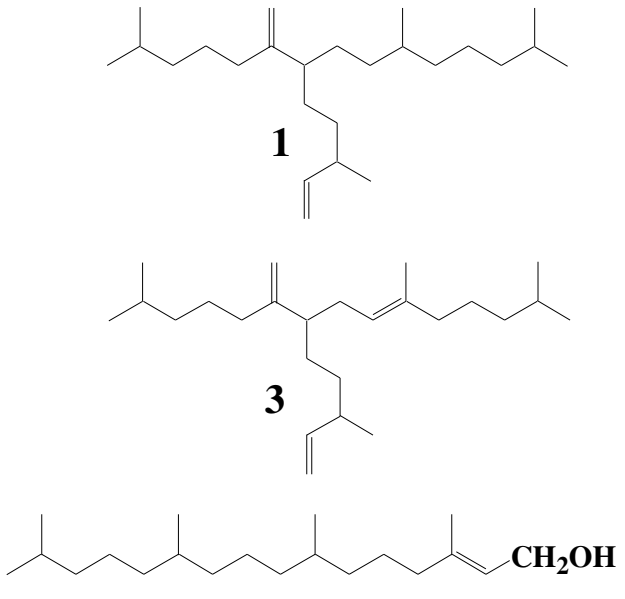

4

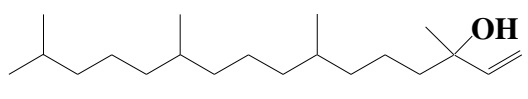

6

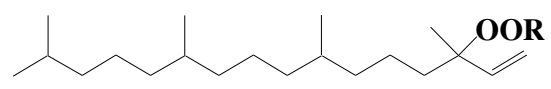

8

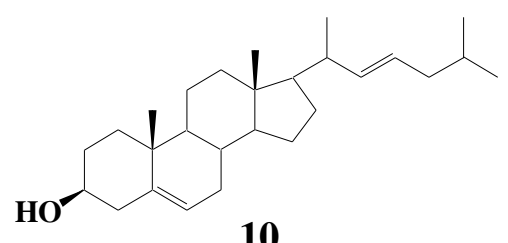

10

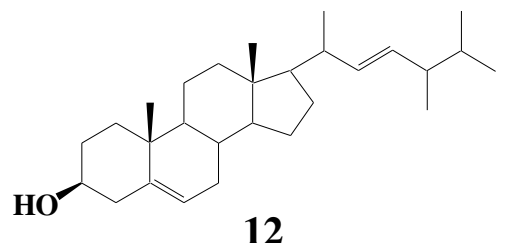

12

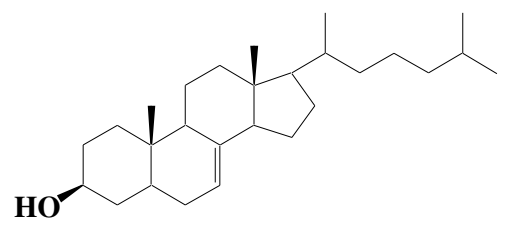

14
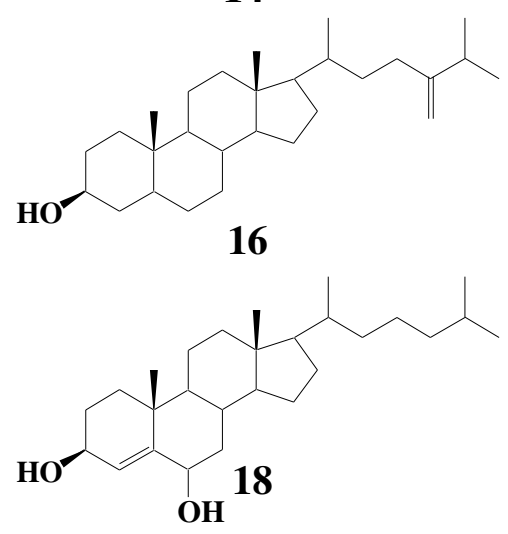
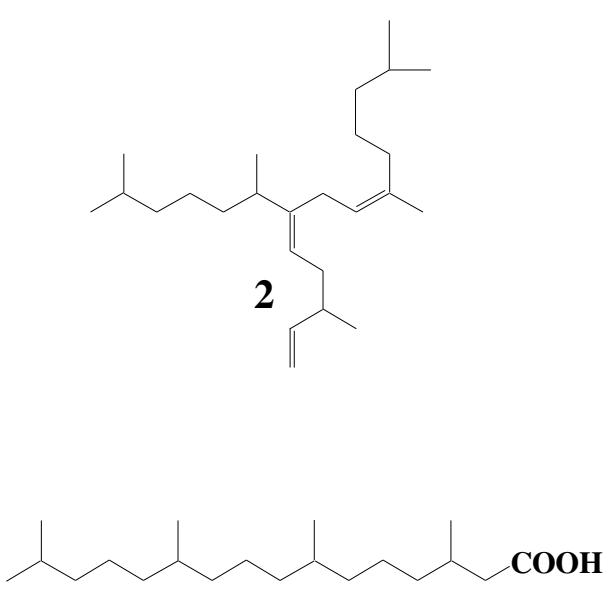

5

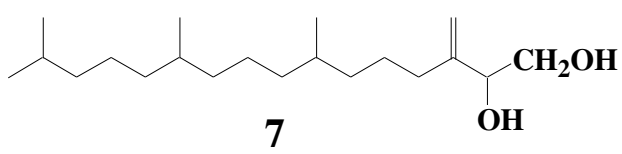

$\mathrm{CH}_{2} \mathrm{OOR}$

9

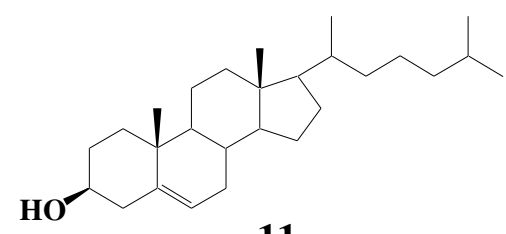

11

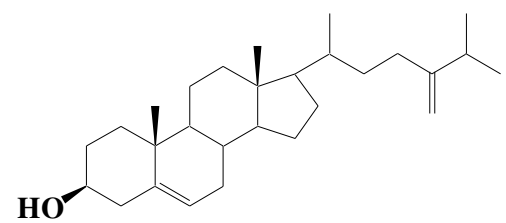

13

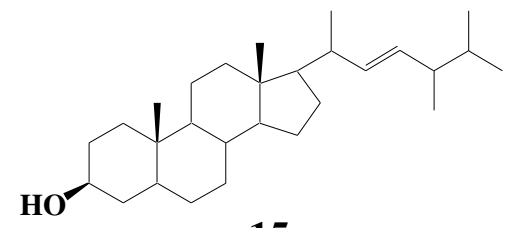

15
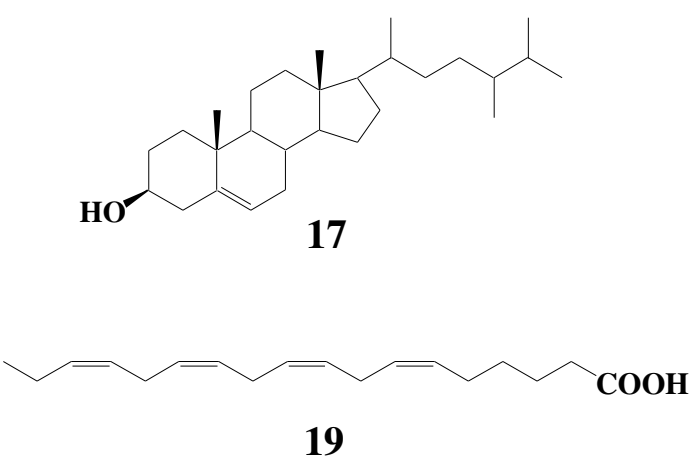

39 


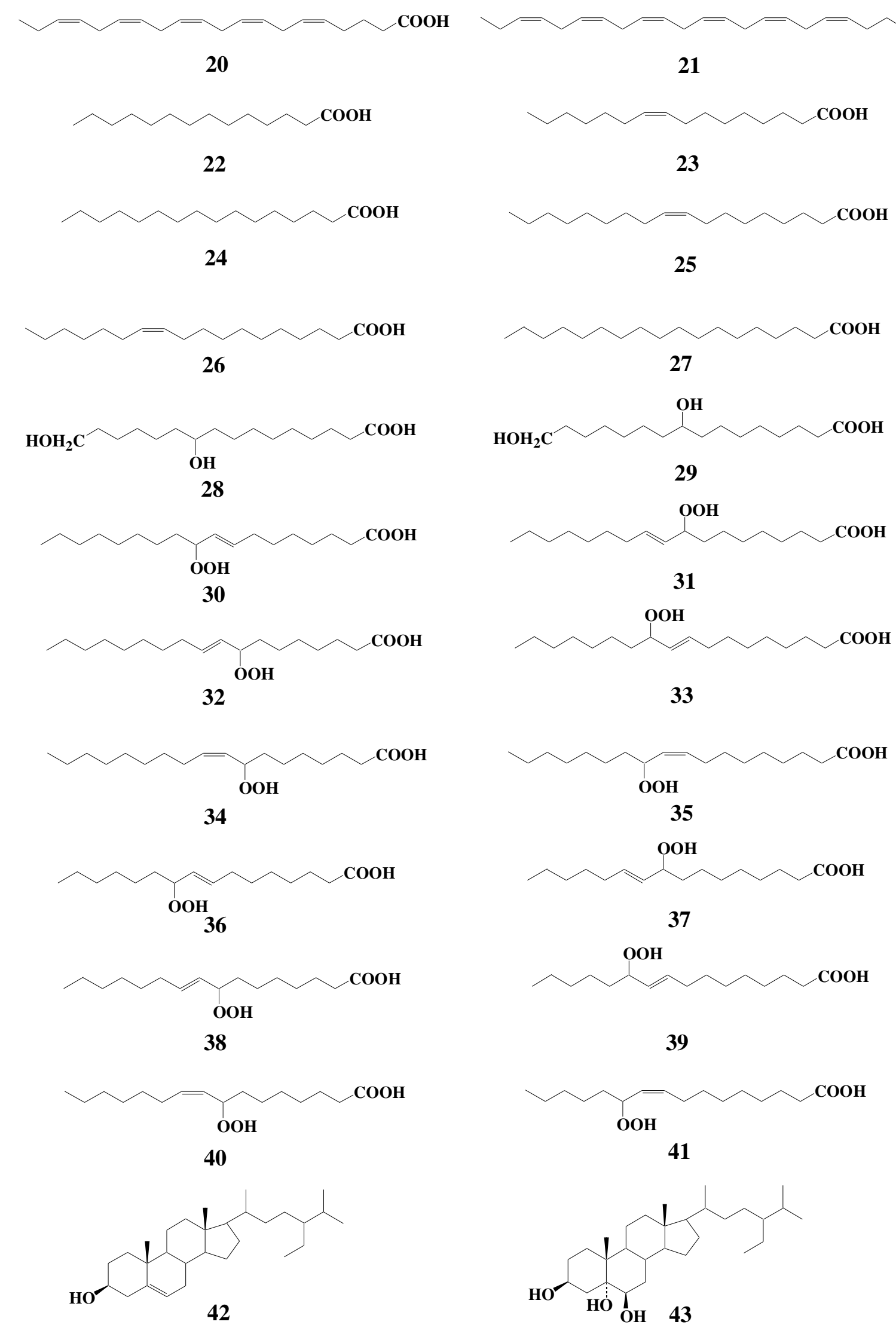

$\mathrm{COOH}$ 


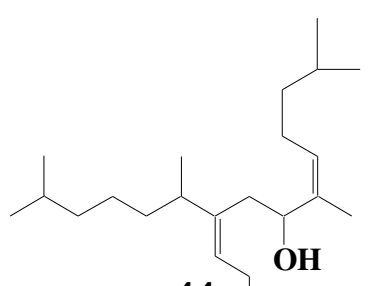

44

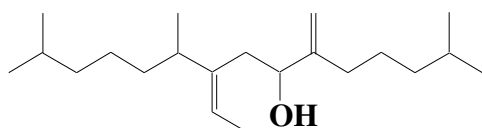

46

$\pi$

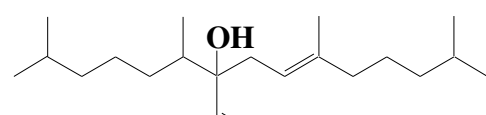

48

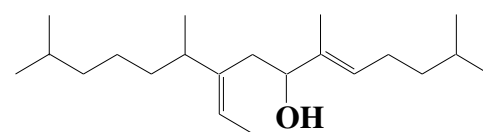

45

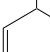

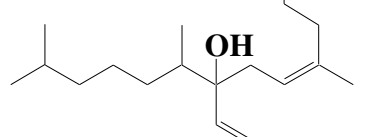

47 
Figure 1. Summary map showing sampling locations $(\mathrm{CB}=$ Commonwealth Bay).

900

Figure 2. Proposed pathways for autoxidation of chlorophyll phytyl side chain.

902

903

Figure 3. Photooxidation percentages of epi-brassicasterol (12), 24-methylenecholesterol

904

(13) and chlorophyll in the CTD samples collected at the stations selected for lipid

oxidation product analyses. The very low photooxidation percentages of sterols in the samples collected at the station 32 were not included in this figure.

907

Figure 4. Photo- and autoxidation percentages of palmitoleic (23) and oleic (25) acids in the CTD samples collected at the stations selected for lipid oxidation product analyses. The weak oxidation percentages of palmitoleic acid in the samples collected at the station 32 are given in Table 3 .

912

Figure 5 . MRM chromatograms $(\mathrm{m} / \mathrm{z} 213 \rightarrow 117, \mathrm{~m} / \mathrm{z} 213 \rightarrow 123$ and $\mathrm{m} / \mathrm{z}, 213 \rightarrow 157)$ for Commonwealth Bay (B). 
917 Figure 6. MRM chromatograms $(\mathrm{m} / \mathrm{z} 295 \rightarrow 93, \mathrm{~m} / \mathrm{z}, 295 \rightarrow 107$ and $\mathrm{m} / \mathrm{z} 295 \rightarrow 183)$ for

918 standard oxidation products of the HBI III (2) (A) and CB phytoplanktonic sample

919 collected from Commonwealth Bay (B).

920

921 Figure 7. Conceptual scheme summarizing sedimentation and degradation of ice algae and

922 open water phytoplankton in east Antarctica. Note that in some cases the increase of the

923 ratio $\mathrm{IPSO}_{25}(\mathbf{1}) / \mathrm{HBI}$ III (2) with depth may be due to the faster sedimentation rate of

924 aggregated sympagic algae relative to open water phytoplankton and in other cases to an

925 intense photooxidation (in the euphotic layer) or autoxidation (in the entire water column and in the oxic layer of sediments) of HBI III (2). 


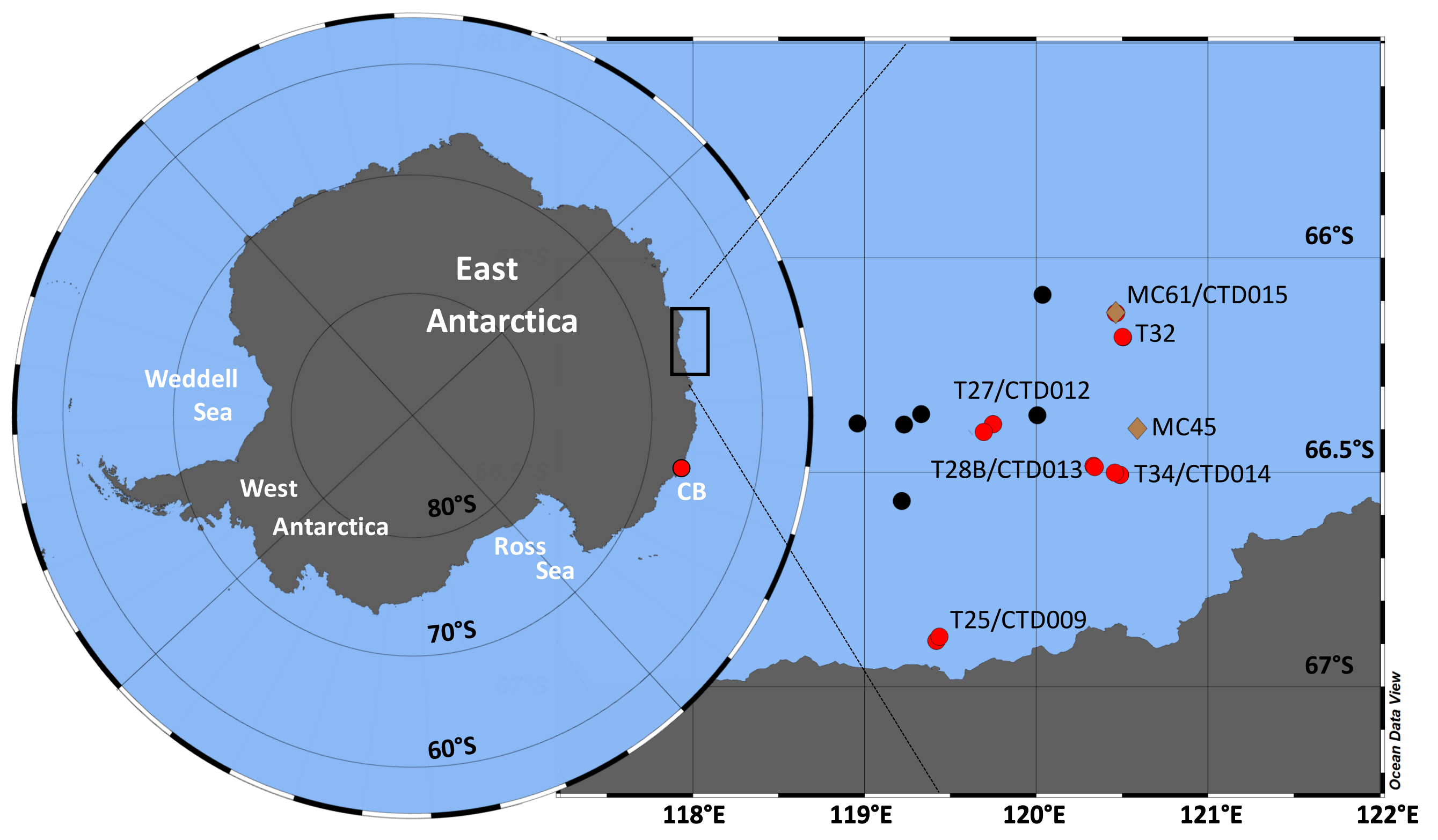

Detailed lipid analysis (oxidation products)

- Other CTD stations (native lipids only)

$\diamond$ Sediments (Megacores) 

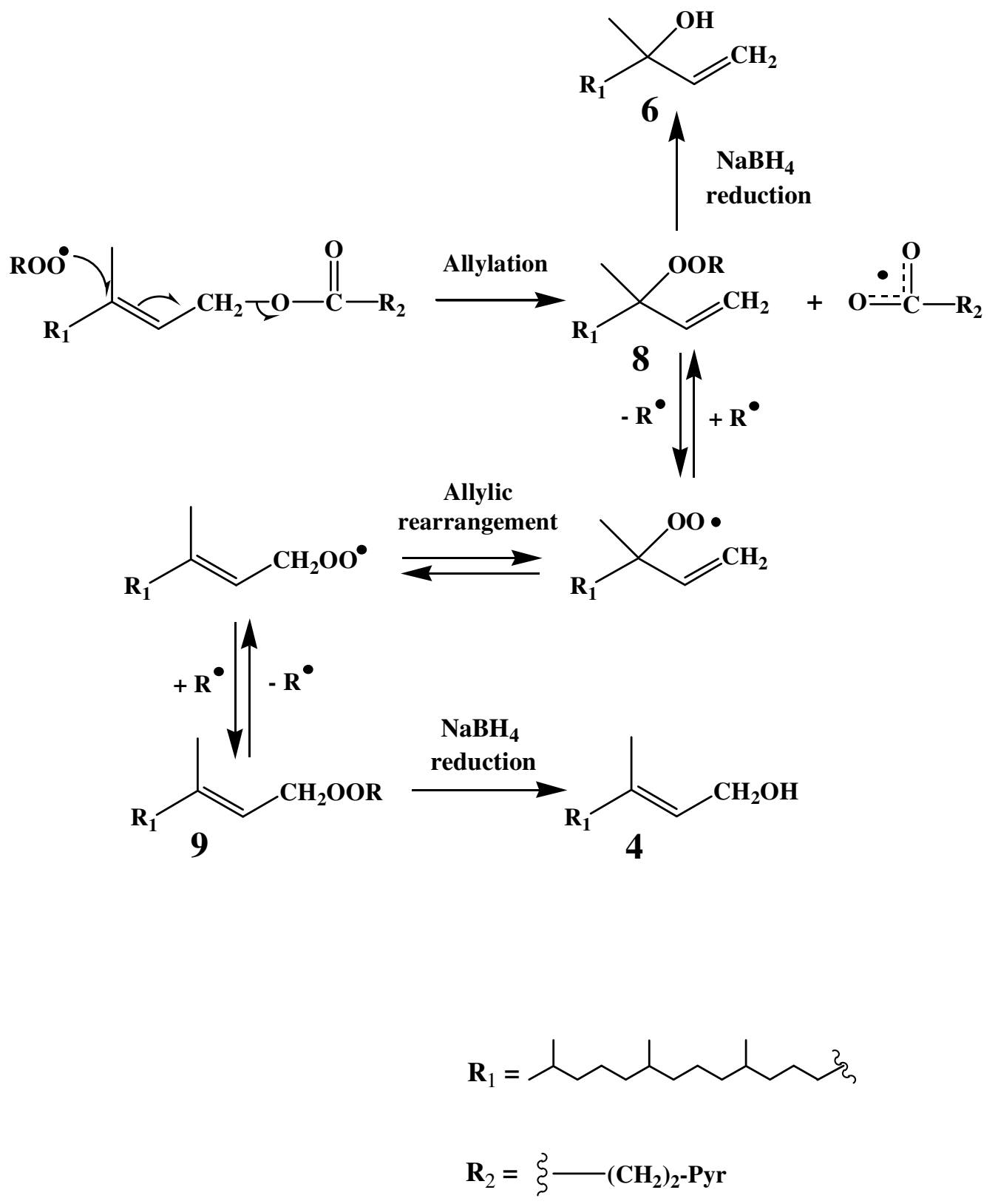

Pyr $=$ More or less oxidized tetrapyrrolic structure 

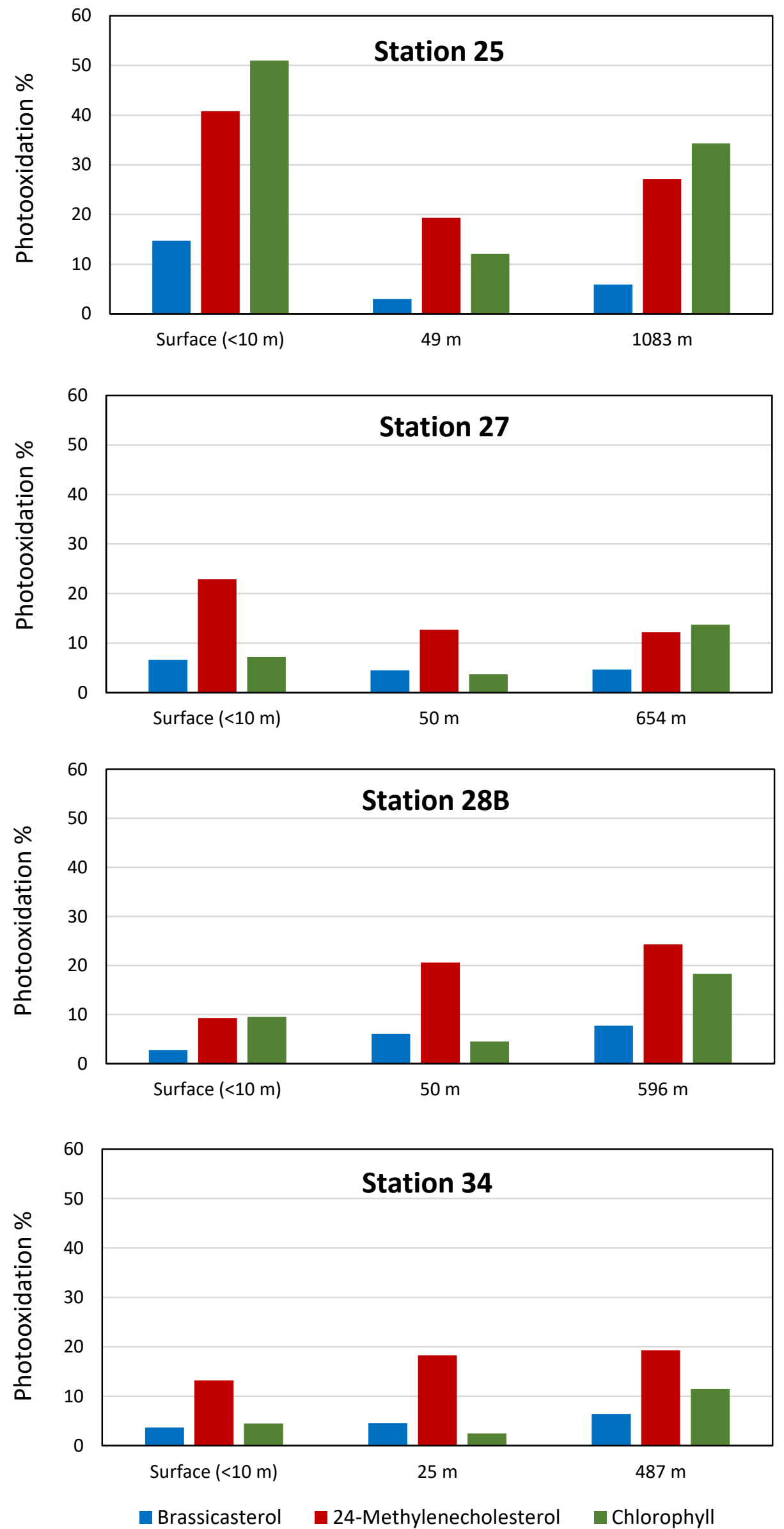

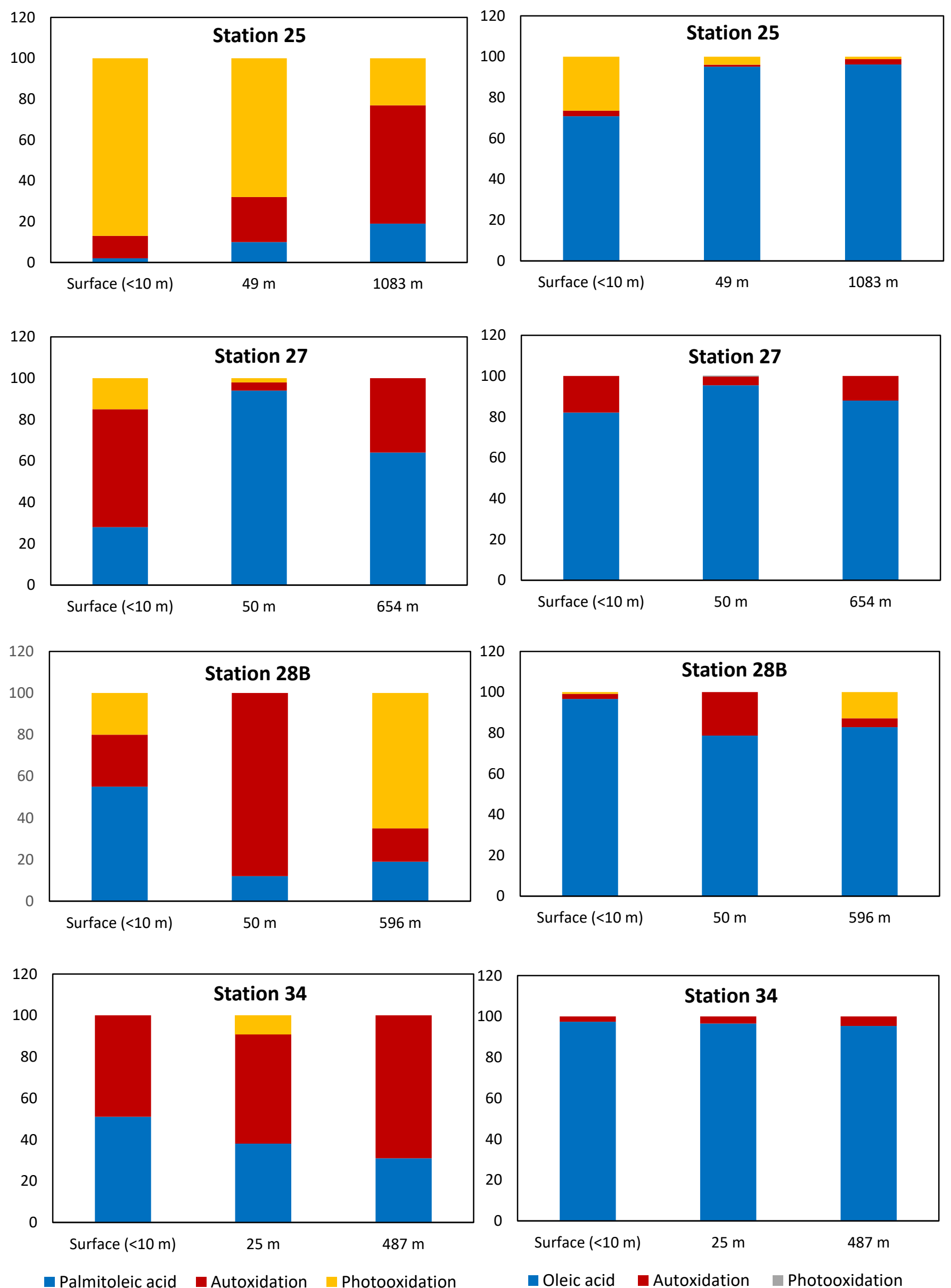


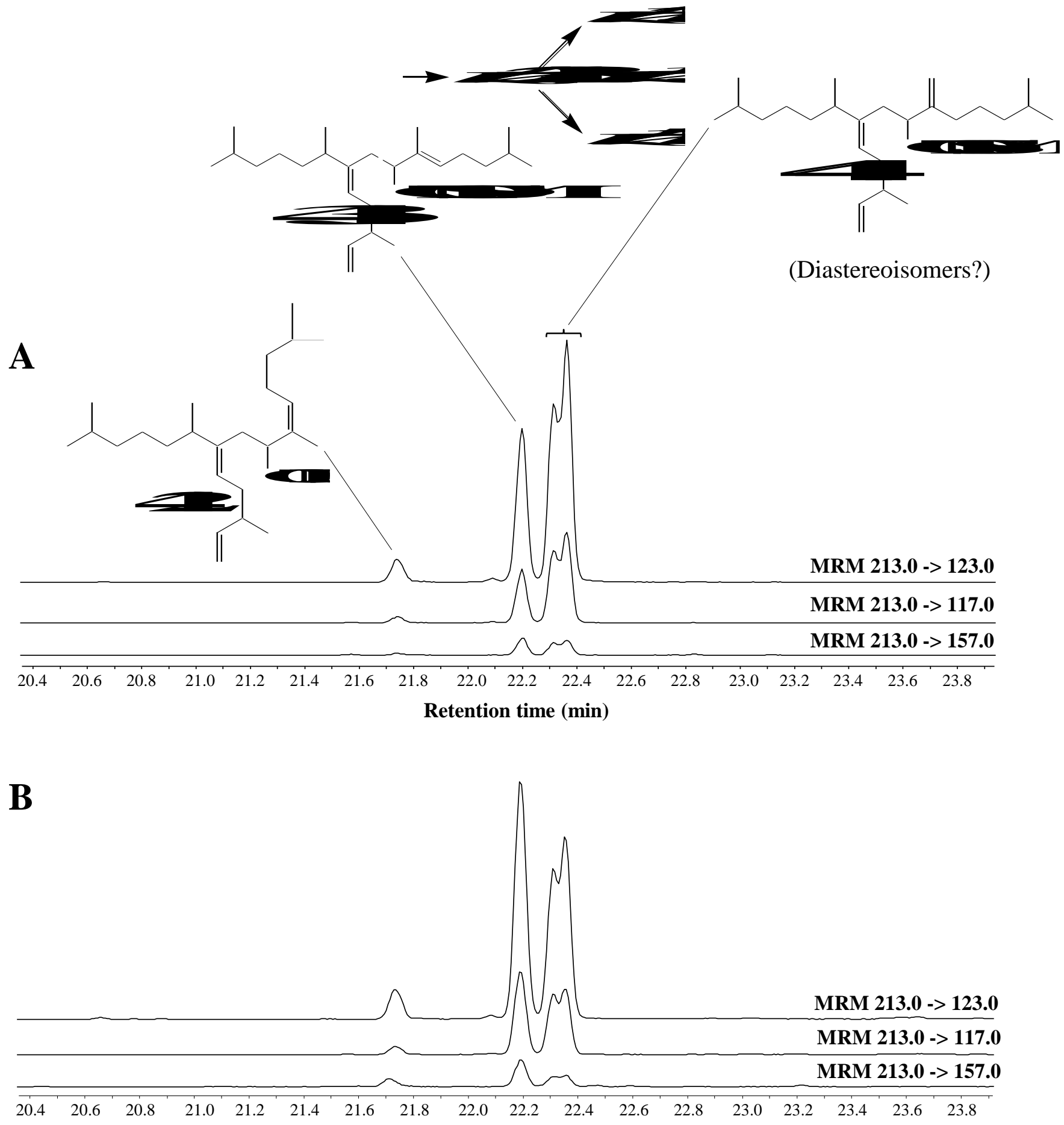

Retention time (min) 


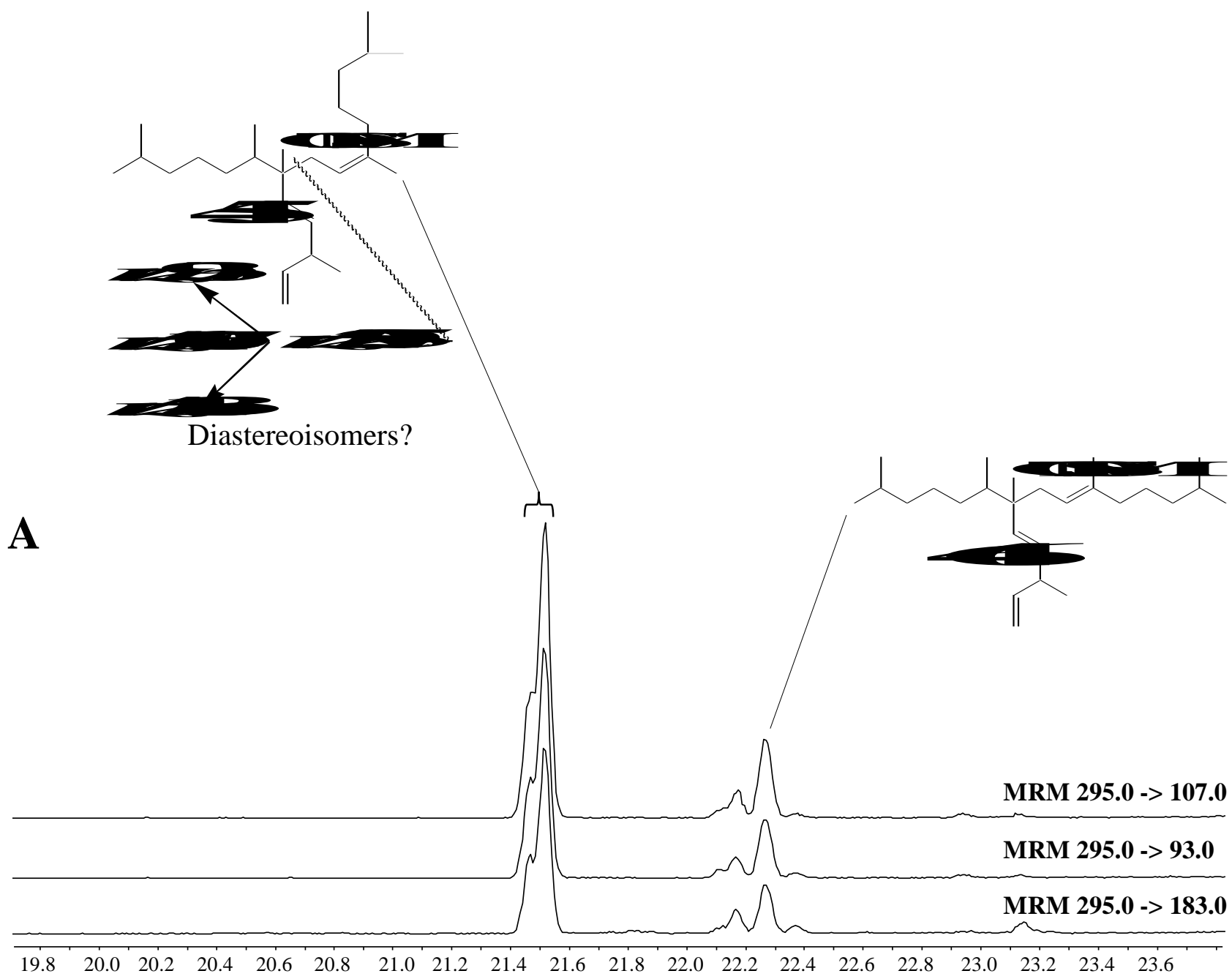

\section{Retention time (min)}

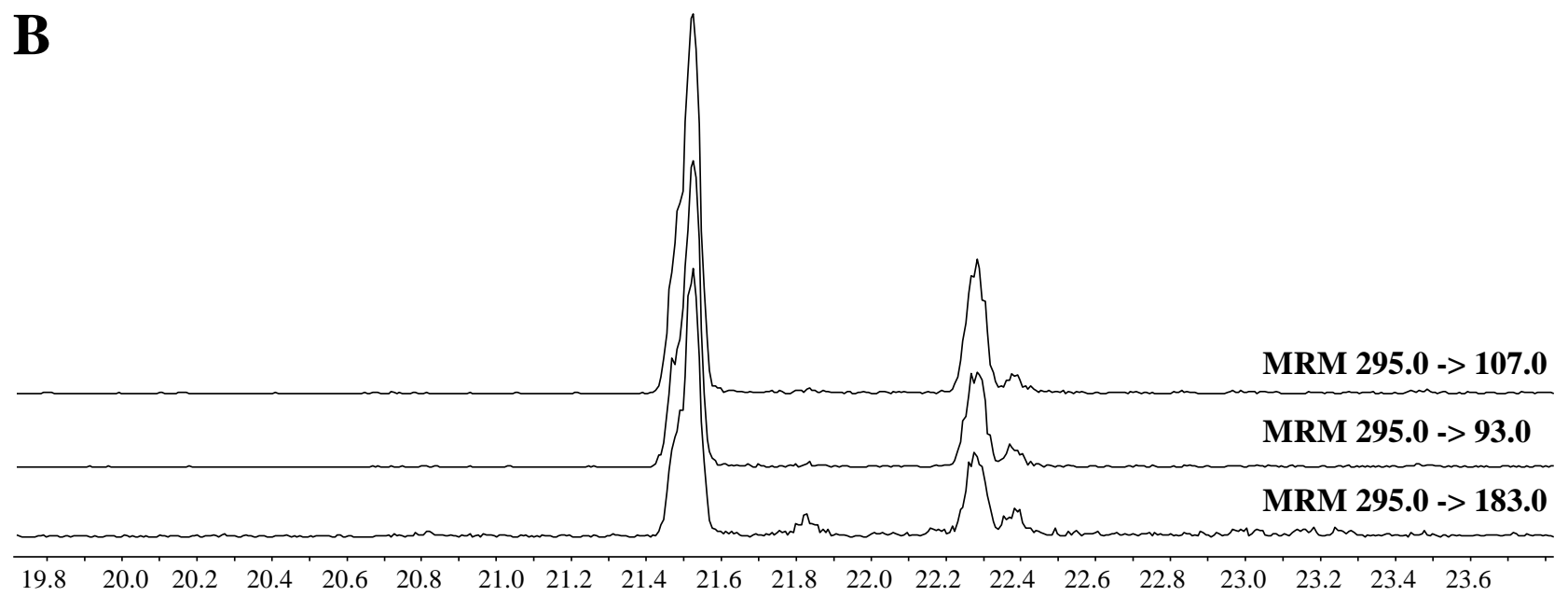

Retention time (min) 


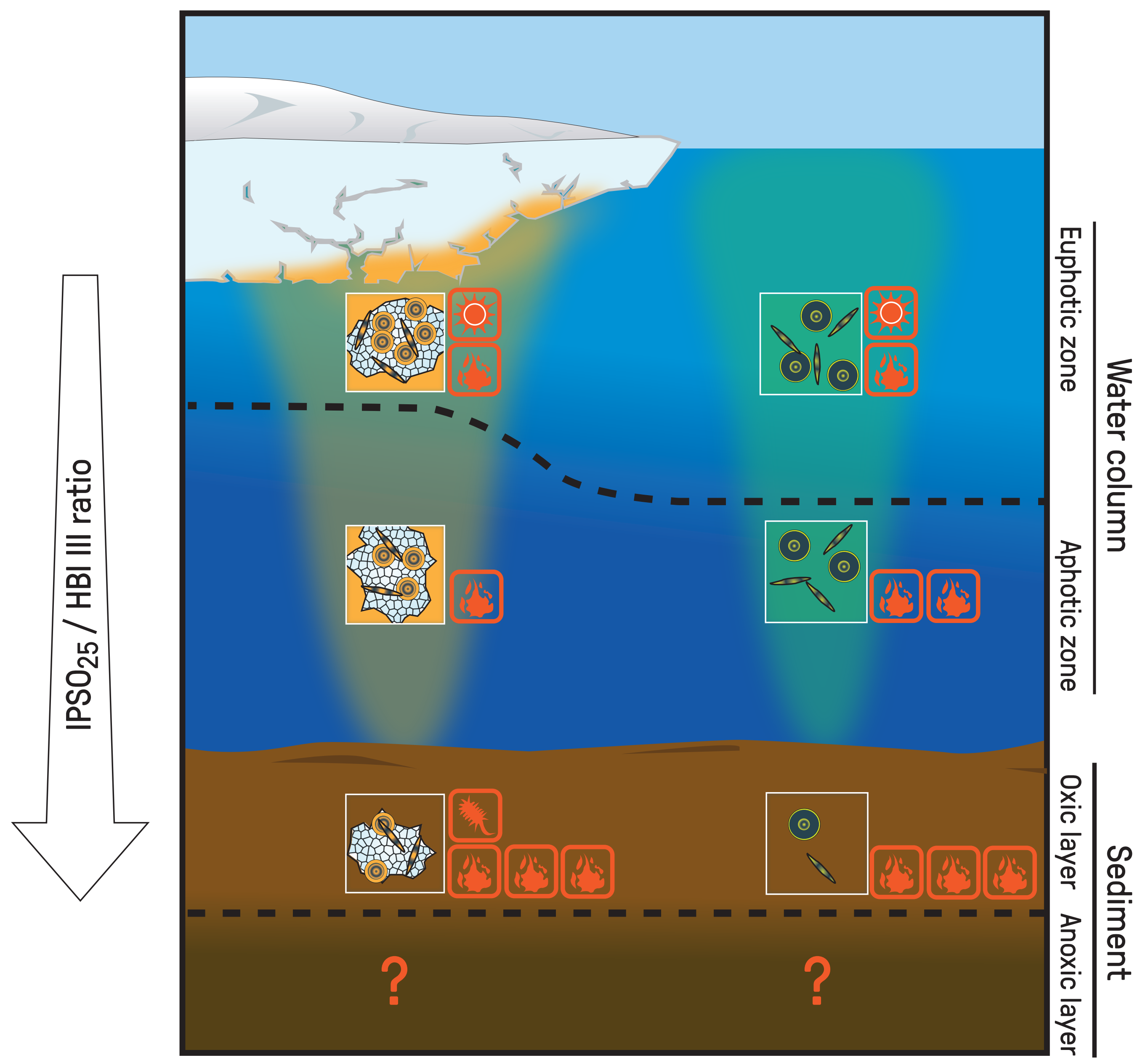

Extracellular polymeric substances - Sympagic algae (O) Phytoplankton

Degradation pathways: 
Table 1

Different indicators measured at the five stations selected for lipid degradation analyses.

\begin{tabular}{|c|c|c|c|c|c|c|}
\hline Station & $\begin{array}{l}\text { Depth } \\
\text { (m) }\end{array}$ & $\begin{array}{c}\mathrm{IPSO}_{25}(\mathbf{1}) / \mathrm{HBI} \\
\mathrm{III}(\mathbf{2})\end{array}$ & $\begin{array}{l}\text { Cuticular waxes }{ }^{\mathrm{a}} \\
\text { palmitic acid (24) }\end{array}$ & $\begin{array}{c}\text { Epi-brassicastanol (12)/ } \\
\text { epi-brassicasterol (16) }\end{array}$ & $\begin{array}{c}\left(\text { Palmitoleic acid }(\mathbf{2 3})+\mathrm{ox}^{\mathrm{b}}\right) / \\
\text { palmitic acid }(\mathbf{2 4})\end{array}$ & $\begin{array}{l}\text { Isophytol (6)/ } \\
\text { phytol (4) }\end{array}$ \\
\hline 25 & $<10$ & 0.21 & 0 & 0.24 & 30.91 & 0.45 \\
\hline 25 & 49 & 0.26 & 0 & 0.20 & 3.42 & 1.64 \\
\hline 25 & 1083 & 2.57 & 0 & 0.32 & 1.65 & 0.60 \\
\hline 27 & $<10$ & 0.26 & 0.07 & 0.17 & 1.82 & 0 \\
\hline 27 & 50 & 0.14 & 2.15 & 0.21 & 0.42 & 0.01 \\
\hline 27 & 654 & 1.74 & 0 & 0.29 & 0.25 & 0.08 \\
\hline $28 \mathrm{~B}$ & $<10$ & 0.51 & 0.02 & 0.14 & 1.01 & 0.30 \\
\hline $28 \mathrm{~B}$ & 50 & 0.44 & 0.03 & 0.24 & 3.11 & 0.06 \\
\hline $28 \mathrm{~B}$ & 596 & 1.61 & 0 & 0.16 & 4.02 & 0.20 \\
\hline 32 & $<10$ & 0.21 & 0 & 0.10 & 0.05 & 0.13 \\
\hline 32 & 40 & 0.37 & 0 & 0.09 & 0.08 & 0.08 \\
\hline 32 & 563 & 0.88 & 0 & 0.17 & 0.02 & 0.07 \\
\hline 34 & $<10$ & 0.25 & 0.04 & 0.14 & 1.11 & 0.04 \\
\hline 34 & 25 & 0.21 & 1.23 & 0.17 & 1.10 & 0.05 \\
\hline 34 & 487 & 1.54 & 0 & 0.28 & 1.36 & 0.03 \\
\hline
\end{tabular}

${ }^{\text {a }}$ Mixtures of 9,16-dihydroxyhexadecanoic (29) and 10,16-dihydroxyhexadecanoic (28) acids

${ }^{\mathrm{b}}$ Photo- and autoxidation products 
Table 2

Comparison of the ratio $\mathbf{1 / 2}$ and the autoxidation state of some other algal lipids in SPM and underlying sediments. See Fig. 1 for sample locations.

\begin{tabular}{lccccc}
\hline Station - sample type & Depth (m) & $\begin{array}{c}\text { IPSO } 25(\mathbf{1}) / \\
\text { HBI III (2) }\end{array}$ & $\begin{array}{c}\text { Sitosterol (42) } \\
\text { autoxidation } \\
\%\end{array}$ & $\begin{array}{c}\text { Palmitoleic acid } \\
\text { (23) autoxidation \% }\end{array}$ & $\begin{array}{c}\text { (F. curta }+ \text { F. cylindrus) } \\
\text { /F. kerguelensis }\end{array}$ \\
\hline T32 - SPM & $<10$ & 0.2 & 0 & 1.3 & 20.6 \\
CTD015 - SPM & 40 & 0.4 & 0 & 9.3 & 18.8 \\
CTD015 - SPM & 563 & 0.9 & 0 & 21.8 & 0.0 \\
MC61 - overlying water & 579 & 1.6 & $*$ & $*$ & N/A \\
MC61 - diatomaceous 'fluff' & 579 & 2.6 & $*$ & 53.4 & 0.7 \\
MC61 - sediment (1-2 cm) & 579 & 7.5 & 28.4 & 51.6 & 0.8 \\
MC45 - sediment (1-2 cm) & 538 & 11.3 & 46.3 & & \\
*-not measured & & & &
\end{tabular}


Table 3

Percentage $^{\mathrm{a}}$ of oxidation products of HBI III (2) detected after $\mathrm{NaBH}_{4}$-reduction of filtered phytoplankton from Commonwealth Bay (East Antarctica)

$\mathrm{CB}$
$\mathrm{AS} 607$

${ }^{a}$ Relative to the residual parent HBI

${ }^{\mathrm{b}}$ Coelution problem 
Table 4

Relative percentages of intact hydroperoxides and their ketonic and alcoholic degradation products measured in the case of the main HBI oxidation products present in phytoplankton from Commonwealth Bay (East Antarctica) (CB sample).

$\mathrm{X}-$

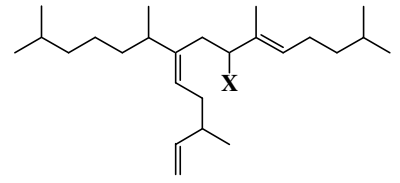

18

1

81

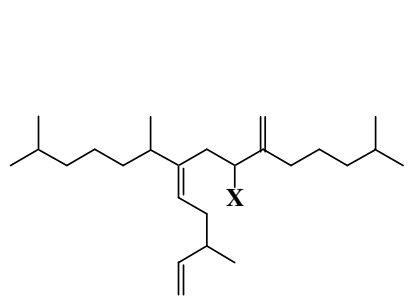

22

3

HOO-

$\mathrm{O}=$

75
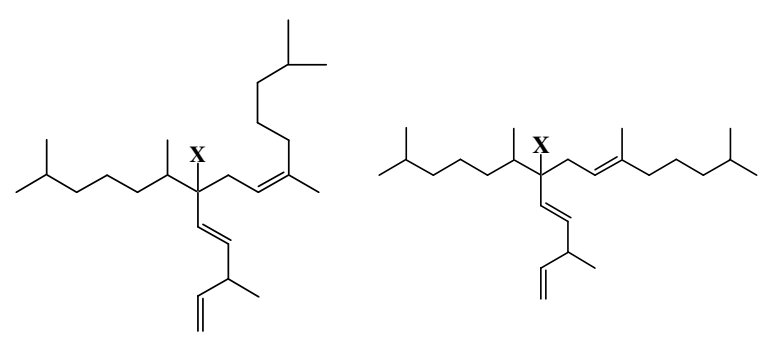

21

45 